\title{
A spontaneously arising mutation in connexin32 with repeated passage of FRTL-5 cells coincides with increased growth rate and reduced thyroxine release
}

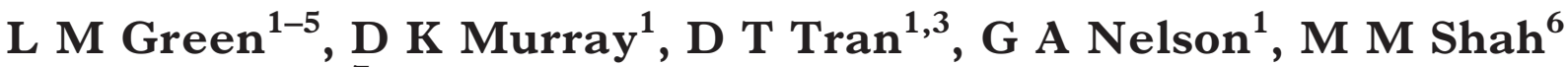 and $\mathbf{R} \mathbf{A}$ Luben ${ }^{7}$}

${ }^{1}$ Radiobiology Program, Department of Radiation Medicine, Chan Shun Pavilion, Room A-101,
Loma Linda University, 1175 Campus Street, Loma Linda, California 92354, USA
${ }^{2}$ Molecular Immunology, JL Pettis Memorial Veterans Medical Center, Research Service 151,
11201 Benton Street, Loma Linda, California 92357, USA
${ }^{3}$ Department of Microbiology \& Molecular Genetics, Loma Linda University Graduate School,
Loma Linda, California 92354, USA
${ }^{4}$ Department of Physiology, Loma Linda University Graduate School, Loma Linda, California
92354, USA
${ }^{5}$ Loma Linda University Medical School, Department of Rheumatology, Loma Linda, California
92354, USA
${ }^{6}$ The Scripps Research Institute, Department of Cell Biology, MB116, 10550 North Torrey Pines,
La Jolla, California 92037, USA
${ }^{7}$ Division of Biomedical Sciences, University of California Riverside, Riverside, California 92521, USA

(Requests for offprints should be addressed to L M Green, Radiobiology Program, Department of Radiation Medicine, Chan Shun Pavilion, Room A-101, Loma Linda University, 11175 Campus Street, Loma Linda, California 92354, USA; Email: lgreen@dominion.llumc.edu)

\begin{abstract}
In this study we examine changes in the cellular properties of FRTL-5 cells as a function of passage number, with particular emphasis on gap junction expression, karyotype, morphology, growth rate and thyroxine $\left(\mathrm{T}_{4}\right)$ release. Early passage FRTL-5 follicular cells transfer dye through gap junctions from injected cell(s) to third-order neighboring cells and beyond within their respective follicles and have immuno-detectable connexin32 (Cx32) type gap junctional plaques in their lateral contacting plasma membranes. By contrast, FRTL-5 cells established as monolayers, or as follicles from cultures passed more than 15 times, did not transfer microinjected Lucifer Yellow dye to contiguous neighboring cells and did not express any immunodetectable rat thyroid specific connexins $(\mathrm{Cx} 43$, Cx32 or Cx26). Western blots confirmed that total, membrane and cytosolic $\mathrm{Cx} 32$ protein was present only in early pass follicular cultures. To better understand the passage-dependent loss of $\mathrm{Cx} 32$ expression, RT-PCR primers were made to the most unique sequences of the rat $\mathrm{Cx} 32$ molecule, the cytoplasmic and carboxyl-terminal regions. These primers were used to screen FRTL-5 RNA
\end{abstract}

from cultures of various passage numbers. The results revealed that later passage cultures had a single base deletion in the middle of the $\mathrm{Cx} 32$ cytoplasmic loop region at nucleotide position 378 . This base deletion was in the middle position of the codon for amino acid 116, which is normally a CAC (histidine) but read with the frame shift was a CCC (proline). The four amino acids that followed this deletion were also altered with the fourth one becoming UAA, the ochre translation stop codon. This premature stopping of translation resulted in a truncation of $60 \%$ of the protein, which included the remaining cytoplasmic loop, third and fourth transmembrane regions and the carboxyl-terminus. The later passage cultures did not produce a carboxyl-terminal RT-PCR product, indicating that the mRNA was also truncated. These regions of the Cx32 molecule contain the sequences and epitopes to which probes and antibodies are directed, and as such alterations of these regions with repeated passage explains reports by others that FRTL-5 cells do not express $\mathrm{Cx} 32$, and implies that cultures used for these assessments were passed more than 15 times. To determine if genetic or epigenetic 
abnormalities existed in FRTL-5 cells we performed chromosome spreads from various passage cultures. FRTL-5 cells have been reported to be diploid and more recently non-diploid; however, we found them to be fully tetraploid. This tetraploidy appears to be unstable in that later passes are tetraploid plus two or three extra chromosomes. There were no obvious translocations, breaks or large-scale interstitial deletions of any chromosomes in the FRTL-5 cultures tested. As FRTL-5 cells were repeatedly passed their morphology changed. Monolayer areas spread from beneath the follicles, and the follicles became flattened in appearance. These physical changes were coincident with dramatically increased growth rates. Early cultures (passed 3-12 times) divided on average every $49 \pm 1 \mathrm{~h}$, whereas later passes (passes 20-25) divided every $28 \pm 3 \mathrm{~h}$. To correlate these changes with a measure of thyroid function we assayed $\mathrm{T}_{4}$ output. Early passage follicular cultures incubated for $6 \mathrm{~h}$ with sodium iodide, released on average $5 \cdot 27 \pm$ $0.33 \mathrm{ng} / \mathrm{ml}$ of $\mathrm{T}_{4} / 100$ follicles. Later passes, or early passes treated with heptanol to down-regulate $\mathrm{Cx} 32$, released an average of $3.84 \pm 0.50 \mathrm{ng} / \mathrm{ml}$ of $\mathrm{T}_{4} / 100$ follicles. There was a $27 \%$ difference in $\mathrm{T}_{4}$ release between early follicular cultures, that were coupled by $\mathrm{Cx} 32$, and late or down-regulated early follicular cultures, that were uncoupled $(P<0 \cdot 0001)$. Collectively, the physical changes documented in this study were coincident with the loss of functional $\mathrm{Cx} 32$. This implies a relationship between the loss of intercellular communication and changes in morphogenic appearance, growth rate and reduced thyroid function and supports the previously postulated, tumor-suppressor role for $\mathrm{Cx} 32$. FRTL-5 cultures from low passage numbers are an excellent model of primary thyroid cells. However, many reports in the literature ascribe features to FRTL-5 cells that are mutually inconsistent. These differences may be resolved in the future by addressing the passage number and the conditional differences of the cultures being studied.

Fournal of Molecular Endocrinology (2001) 27, 145-163

\section{INTRODUCTION}

The FRTL-5 cell line was derived from a Fischer rat primary thyroid culture and found to be similar to primary thyroid cells in their growth properties and thyroid-stimulating hormone (TSH) dependence. Since their commercial introduction by Ambesi-Impiombato, Parks \& Coon in 1980 (Ambesi-Impiombato et al. 1980), FRTL-5 cells have been the subject of more than 650 published studies. These investigations fall into a dozen or so categories, emphasizing thyroid and TSH receptor function, organification, signal transduction and follicular assembly (Chen et al. 1993, Kimura et al. 1997, Cavalieri et al. 1999, Suzuki et al. 1999, Ariga et al. 2000).

Normal rat thyroid cells express three wellcharacterized connexin $(\mathrm{Cx})$ proteins: $\mathrm{Cx} 43, \mathrm{Cx} 32$ and Cx26 (Meda et al. 1993, Green et al. 1996). Connexin monomers form hexameric rings in the plasma membranes of contacting cells. When two connexin hemi-channels in adjacent cells unite, they form a complete channel or connexon. Through lateral diffusion aggregates of multiple connexons form a gap junction (Unwin \& Zampighi 1980). Gap junctions establish cytoplasmic continuity between coupled cells and regulate numerous cellular properties, including growth and differentiation (Loewenstein 1979, Salomon \& Meda 1986, Dermietzel 1993, Holder et al. 1993, Temme et al. 1997). We have previously documented that in organized rat thyroid follicles the three connexins assemble at different thyrocyte cell surfaces: $\mathrm{Cx} 43$ localizes at the basal surface connecting cells in adjacent follicles; $\mathrm{Cx} 32$ at the lateral surface unites cells within a follicle; and $\mathrm{Cx} 26$ at apical surfaces faces the lumen (Green et al. 1996). There is a morphogenic control over the expression of $\mathrm{Cx} 43$ and $\mathrm{Cx} 32 . \mathrm{Cx}_{4} 43$ predominates when the cells are in monolayers, and $\mathrm{Cx} 32$ gap junctions assemble as the cells undergo follicularization (Munari-Silem et al. 1994, Green et al. 1996, 1997). The location of Cx26 suggests that it is transported to the apical surface by vesicular transport from the trans-Golgi complex once the polarity is established by the lateral assembly of tight and adherens junctions (Yap et al. 1995).

An important aspect of endocrine/exocrine glands is their polarized assembly, which at the most intimate level includes gap junctions (Meda et al. 1993). Cx43, Cx32 and Cx26 are regulated differently (Saez et al. 1993), and associate with different thyrocyte cell surfaces (Meda et al. 1993, Guerrier et al. 1995, Green et al. 1995a, 1996) wherein they are expected to contribute to different aspects of thyroid function. The location of $\mathrm{Cx} 32$ at the lateral surfaces of follicular thyrocytes establishes metabolic cooperativity between the coupled cells. This allows them to act collectively in their response to TSH/cAMP signaling and subsequent thyroid hormone release. Thus, the histotypic up-regulation of $\mathrm{Cx} 32$ with follicularization (Munari-Silem et al. 
1994) and its lateral location implies that of the connexins, $\mathrm{Cx} 32$ is most important to coordination of thyrocytes organized as follicles (Green et al. 1995a, 1996).

Gap junctions have been postulated to serve as tumor suppressor proteins, in that, when absent, either physically or functionally, the uncoupled cells have dramatically increased growth rates (Temme et al. 1997, Mehta et al. 1999, Yamasaki et al. 1999a). Cx32 is the predominant connexin in liver and when down-regulated either naturally or artificially (knockout mice), the incidence of hepatocarcinoma is greatly increased (Tsuda et al. 1996, Temme et al. 1997). When Cx32 was re-introduced by transfection into FRTL-5 cells, that were not expressing $\mathrm{Cx} 32$, their growth rates were substantially reduced (Statuto et al. 1997).

Individual follicles are discrete functional units of the thyroid gland and the lateral assembly of Cx32 gap junctional channels in part establishes their coordinated function. This is exemplified under conditions of inflammatory injury, where the decreased expression and function of $\mathrm{Cx} 32$ contributes to the resulting hypothyroidism. Normally, gap junction-competent thyroid follicles respond to TSH signaling collectively, via their $\mathrm{Cx} 32$ junctional channels, and release the required levels of the thyroid hormones. In gap junctionuncoupled thyroid follicles the response to TSH by individual thyrocytes is insufficient to meet the demand and so the levels of TSH remain elevated (Green et al. 1995a, 1996, 1997). A similar situation has been documented in beta islet cells of the pancreas. There, the output of insulin by individual cells was significantly less than when they were homotypically coupled by gap junctions (Meda 1989). Thus, for liver, pancreatic islet and thyroid follicles the presence of gap junctions integrates individual cells into functional tissue units, allowing them to regulate their growth and to act collectively in their receipt and response to various signals.

We purchased FRTL-5 cells from the American Type Culture Collection (ATCC) in the early 1990s and maintained them in parallel with our murine (Green et al. 1995a,b) and rat (Green et al. 1996, 1997) primary thyroid cultures. The cultures from early passages $(<15)$ closely resembled primary thyrocytes: they developed into well-defined follicles in culture; required TSH for growth; divided on average every $49 \mathrm{~h}$; and produced thyroxine $\left(\mathrm{T}_{4}\right)$ when supplied with iodide. We continued to carry FRTL-5 cells comparing them to primary rat thyroid cultures, and have compiled information regarding the conditional dependence of their functional properties.
In this report we address phenotypic changes in FRTL-5 cells as a function of passage number, including gap junction expression, karyotype, morphology, growth rate and $\mathrm{T}_{4}$ release. Additionally, we discuss how some apparently conflicting reports in the literature can be explained by differing conditions and/or passage numbers.

\section{MATERIALS AND METHODS}

\section{Fisher rat thyroid cell line/tissue culture}

FRTL-5 cells were purchased from the ATCC (Manassas, VA, USA). Upon receipt, the cells were growth expanded and samples were stored frozen in liquid nitrogen. The cells used in these experiments were derived from our pass 3 through pass 25 FRTL-5 stocks. Our care and feeding of these cells has been previously described (see Green et al. 2001). For clarification, Ham's modified F-12 is the medium specified by ATCC, we however, maintain our FRTL-5 cells in DMEM:F12 (50:50 v/v). We grew the FRTL-5 cells in both media for comparison prior to switching to the DMEM:F12 mix. There were no differences in the growth or physical properties of the cells grown in the two different media. We therefore opted to use the same medium that we developed for use with our primary rodent thyroid cultures (Green et al. 1995a). The calf serum used has been from two pre-tested lots, one purchased in 1993 and more recently a restock in 1998 (Summit Biotechnologies, Ft Collins, CO, USA). When $\mathrm{T}_{4}$ measurements were to be taken, $1 \mathrm{nM}$ sodium iodide was added to the complete culture medium at least $6 \mathrm{~h}$ prior to harvesting supernatant. To test for $\mathrm{T}_{4}$ release in cultures with down-regulated $\mathrm{Cx} 32$ gap junctions, $3 \mathrm{mM}$ heptanol was added to established follicular cultures $1 \mathrm{~h}$ prior to the addition of sodium iodide.

\section{Microinjection}

The electrophysiological measurements were done as previously described (Green et al. 1995a). All observations and microinjections were performed on an Olympus IX-70 optical base (Scientific Instruments, Temecula, CA, USA) equipped with long working distance objectives and a C-mount analog color camera (Oly-750). The camera was connected to an image processing system (ImagePro Plus version 4, Media Cybernetics, Silver Springs, MD, USA) operated by a computer $(200 \mathrm{MHz}$ Pentium PC). Fluorescent images were captured and stored as TIFF files. 


\section{Fluorescence immunocytochemistry}

FRTL-5 cells established on coverslips were fixed as previously described (Green et al. 1996, 1997). Primary rabbit polyclonal antisera directed against Cx43 (CT-360) were obtained from Dr Dale Laird (Laird et al. 1991) and an additional rabbit polyclonal anti-Cx43 and anti-Cx26 were obtained from Zymed Laboratories, Inc. (San Francisco, CA, USA). Monoclonal antibody against Cx32 was purchased from Chemicon International (Temecula, CA, USA), and a rabbit polyclonal antiserum directed against $\mathrm{Cx} 32$ was obtained from Dr Klaus Willecke (Winterhager et al. 1991). The secondary antibodies, FITC-conjugated goat anti-rabbit IgG and FITC-conjugated donkey anti-mouse $\mathrm{IgG}$ were purchased from Chemicon International.

To reveal the lateral surfaces of organized thyroid follicles, established cultures were gently lifted with collagenase A and centrifuged (1000 r.p.m., 7 min). The pellet was covered in cryoprotectant and frozen. The frozen follicles were cryosectioned, fixed and immuno-labeled as described above. Non-specific fluorescence was determined by incubating replicate coverslips with pooled normal, non-immune sera (Sigma, St Louis, MO, USA) and secondary antibody, or with secondary antibody alone. The fluorescent images were captured using ImagePro Plus software via an Oly-750 analog color camera connected to an Olympus BX-60 microscope (Scientific Instruments).

\section{Protein fractionation, immunoprecipitation and Western blot analyses}

FRTL-5 cells from various passage numbers were grown to approximately $80 \%$ confluence, and cells harvested by scraping in cold immunoprecipitation buffer (IPB; $100 \mathrm{mM} \mathrm{Na} \mathrm{N}_{2} \mathrm{PO}_{4}, 150 \mathrm{mM} \mathrm{NaCl}$, $2 \mathrm{mM}$ EDTA, $1 \mathrm{mM}$ sodium orthovanadate, $\mathrm{pH}$ $7 \cdot 0), 1 \mathrm{ml} / \mathrm{T}-75$ flask. The protein cell lysates were stored on ice and further disrupted by shearing with a 22 -gauge needle. Aliquots $(100 \mu \mathrm{l})$ of the sample solutions were saved (total lysate), and the remaining lysate ultra-centrifuged at $100000 \mathrm{~g}$ for $1 \mathrm{~h}$ at $4{ }^{\circ} \mathrm{C}$ to separate cytosolic from membrane protein. The membrane pellets were then re-suspended with IPB buffer and further sheared with a 25 - and then a 27 -gauge needle. NP-40 $(2 \%, \mathrm{v} / \mathrm{v})$ was added to each sample (total protein lysate, cytosolic, and membrane lysates), followed by the addition of $50 \mu \mathrm{l}$ of Protein A-agarose (Gibco-BRL, Gaithersburg, $\mathrm{MD}$, USA) for $4 \mathrm{~h}$ at $4{ }^{\circ} \mathrm{C}$ to pre-clear any non-specific binding to protein $\mathrm{A}$ agarose. The clarified supernatants were transferred to clean micro-centrifuge tubes and quantified by Bio-Rad (Hercules, CA, USA) protein reagent.

To $100 \mu \mathrm{g}$ protein from the sample cell lysates, $15 \mu \mathrm{g}$ anti-Cx32 were added and incubated at $4{ }^{\circ} \mathrm{C}$ with constant rocking for $16 \mathrm{~h}$. Protein A-agarose beads $(100 \mu \mathrm{l})$ were added to the samples and incubated for an additional $16 \mathrm{~h}$ at $4{ }^{\circ} \mathrm{C}$ with constant mixing. $\mathrm{C} \times 32$-anti- $\mathrm{C} \times 32$ bound agarose beads were collected by centrifugation at $12000 \mathrm{~g}$ for $30 \mathrm{~s}$ and washed three times with immunoprecipitation wash buffer $(0 \cdot 5 \%$ Tween-20, $50 \mathrm{mM}$ Tris $\mathrm{pH} 7 \cdot 5,150 \mathrm{mM} \mathrm{NaCl}, 0 \cdot 1 \mathrm{mM}$ EDTA) and once with triple-distilled $\mathrm{H}_{2} \mathrm{O}$. Cx32-Protein A complex was then re-suspended in $30 \mu \mathrm{l}$ lysis buffer (IPB supplemented with $150 \mathrm{mM} \beta$ mercaptoethanol, $5 \mathrm{mM}$ dithiothreitol, $1 \%$ Triton $\mathrm{X}-100$ and $3 \% \mathrm{SDS}$ ) and incubated for $30 \mathrm{~min}$ at room temperature to release $\mathrm{Cx} 32$ protein from the antibody and Protein A beads.

Western blot procedures have been previously published by Green et al. (1997). Briefly, $15 \mu \mathrm{g}$ of the immunoprecipitated protein samples were mixed with an equal volume of twofold concentrated sample buffer and $30 \mu \mathrm{l}$ were loaded, without prior heating, onto a $10 \%$ Tris-glycine gel (Novex, San Diego, CA, USA). Pre-stained molecular weight markers (Bio-Rad) were denatured at $65{ }^{\circ} \mathrm{C}$ for $5 \mathrm{~min}$ and electrophoresed in parallel on each gel. The membranes were hybridized with $3 \mu \mathrm{g} / \mathrm{ml}$ primary antibody overnight at $4{ }^{\circ} \mathrm{C}$, washed and incubated with $5 \mu \mathrm{g} / \mathrm{ml}$ secondary antibody (Cy-5conjugated donkey anti-mouse $\mathrm{IgG}$ ) in blocking buffer for $4 \mathrm{~h}$ at room temperature. The resulting blots were scanned to TIFF files using a Molecular Dynamics fluorescence analysis system, STORM model 860 (Molecular Dynamics, Sunnyvale, CA, USA) equipped with ImageQuant software.

\section{Molecular biology}

Northern blot analysis

RNA isolation, gels and hybridization protocols used have been previously published (Green et al. 1995a). FRTL-5 cells, established in flasks, were rinsed in serum free medium and $1 \mathrm{ml} / \mathrm{T}-75$ flasks (approximately $5 \times 10^{6}$ cells) of guanidine thiocyanate were added. The RNA was extracted from the cell lysates with phenol followed by alcohol precipitation and quantified by spectrophotometry $\left(A_{260} / A_{280}\right)$. Isolated cDNAs were labeled with ${ }^{32} \mathrm{P}-\mathrm{dCTP}$ using a random priming technique (Feinberg \& Vogelstein 1983). Agarose gels containing approximately $20 \mu \mathrm{g}$ total RNA were electrophoresed, transferred to Hybond-N membranes, u.v. cross-linked, stained with methylene blue and the ribosomal bands marked and photographed. 
TABle 1. Dye transfer in FRTL-5 cells

\section{Degree of transfer ${ }^{a}$}

\begin{tabular}{|c|c|c|c|}
\hline $1^{\circ}$ & $2^{\circ}$ & $\geqslant 3^{\circ}$ & $n^{\mathrm{b}}$ \\
\hline $2^{\mathrm{e}}$ & 1 & 0 & 125 \\
\hline 98 & 90 & 75 & 250 \\
\hline 1 & 0 & 0 & 110 \\
\hline 1 & 1 & 0 & 200 \\
\hline
\end{tabular}

aThe distance of Lucifer Yellow dye transfer from the injected cell to concentric, contacting neighboring cells, measured by degree. Primary transfer $\left(1^{\circ}\right)$, secondary transfer $\left(2^{\circ}\right)$, tertiary $\left(3^{\circ}\right)$ and beyond.

${ }^{\mathrm{b}}$ The number of trial injections.

${ }^{c}$ FRTL-5 cells passed from 5 to 12 times.

${ }^{\mathrm{d} C}$ Cultures dispersed and grown as a single cell layer.

${ }^{\text {e}}$ Percent of cell to which dye is transferred.

${ }^{\mathrm{f}}$ Cultures grown as organized follicles.

${ }^{g}$ FRTL-5 cells passed from 16 to 25 times.

The blots were hybridized with the cDNA probes at $42{ }^{\circ} \mathrm{C}$ for $36 \mathrm{~h}$, washed (twice in $6 \times \mathrm{NaCl}$, $\mathrm{NaPO}$ EDTA (SSPE) at $42{ }^{\circ} \mathrm{C}$ for $15 \mathrm{~min} /$ wash), and placed on Fugi-X-ray film (Fisher Scientific, Tustin, CA, USA) for $72 \mathrm{~h}$. The resultant films were scanned and printed.

\section{$R T-P C R$}

RNA samples isolated from various passage FRTL-5 cultures were tested for expression of rat Cx32 message using the Stratagene ProSTAR HF Single-Tube RT-PCR System (Stratagene, La Jolla, CA, USA), which combines cDNA synthesis and high-fidelity PCR amplification in a one-step format. Primers specific for the cytoplasmic loop (nucleotide position 343-424) and C-terminus (nucleotide position 705-895) of rat $\mathrm{Cx} 32$ were designed using Do Primer (www.DoPrimer.com) (17-19 base pairs (bp) in length), and synthesized in the Center for Molecular Biology and Gene Therapy (Loma Linda University, Loma Linda, CA, USA). The reaction procedure was performed according to the manufacturers' instructions. The mixture contained $39.5 \mu \mathrm{l}$ RNase-free water, $5 \mu \mathrm{l}$ $10 \times \mathrm{RT}$-PCR buffer (provided with the kit), $1 \mu \mathrm{l}$ primer set (sense and nonsense loop or C-terminus, $100 \mathrm{ng} / \mu \mathrm{l}), 1 \mu \mathrm{l} \mathrm{dNTP} \operatorname{mix}(40 \mathrm{mM}), 1 \mu \mathrm{l}$ RNA sample $(200 \mu \mathrm{g} / \mathrm{ml}), 1 \mu \mathrm{l}$ MMLV-RT enzyme, and $0.5 \mu \mathrm{l}$ TaqPlus Precision DNA polymerase. Control vials for the loop and $\mathrm{C}$-terminus received all components except FRTL-5 RNA. The complementary DNA synthesis and PCR took place during 40 cycles of an uninterrupted thermalcycling program - $15 \mathrm{~min}$ of $37^{\circ} \mathrm{C}$ incubation for cDNA synthesis followed by a denaturing step of $1 \mathrm{~h}$ at $95^{\circ} \mathrm{C}$, a template-primer annealing step of
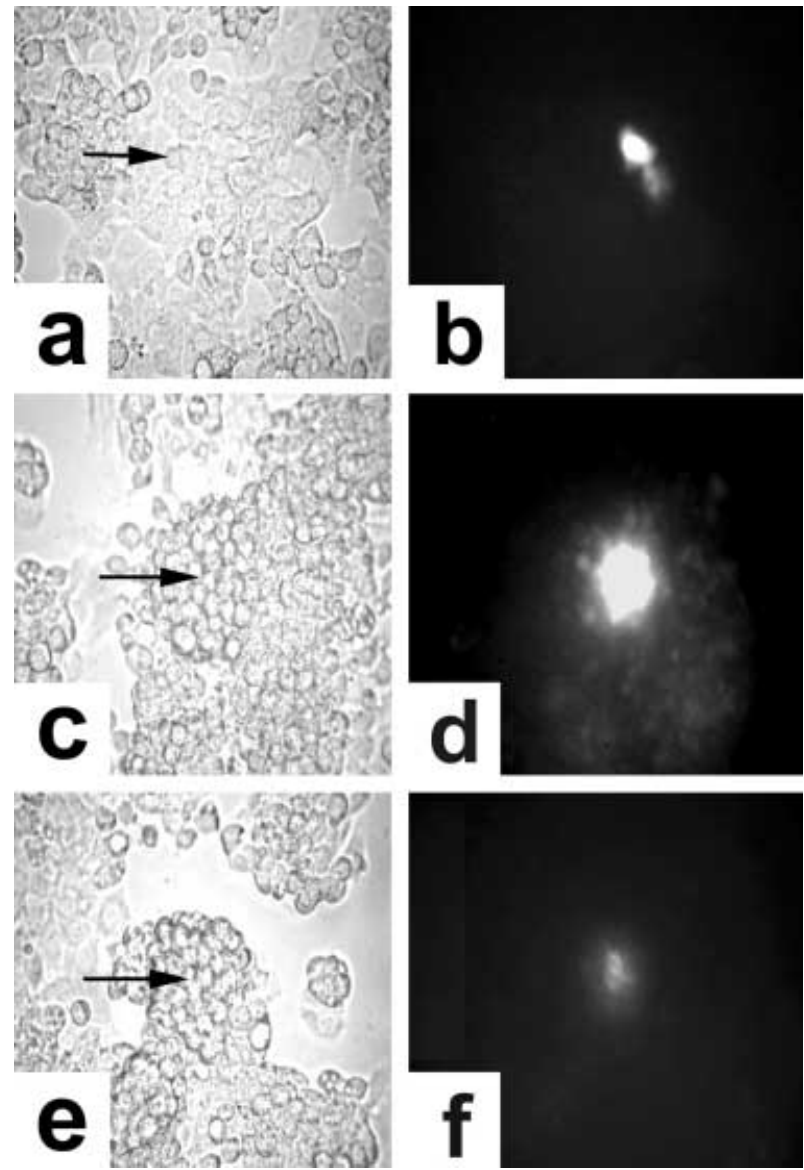

FIGURE 1. Gap junction-mediated cell-to-cell communication in FRTL-5 cells. The composite is arranged with phase images (a, c and e) to the left of the corresponding fluorescent images (b, $d$ and $f$ ). The phase images are shown to indicate the morphology and extent of membrane contact not evident from the fluorescent image alone. Arrowheads indicate the cell that was microinjected with Lucifer Yellow dye. Images were captured within $2 \mathrm{~min}$ post injection. Monolayer cells did not transfer dye to neighboring cells ( $a$ and $b$ ). Early passage FRTL-5 cells (pass 9) transferred dye to contiguous cells within the follicle (c and d). Late passage FRTL-5 cells (pass 21) were severely reduced in their ability to transfer dye (e and $\mathrm{f}$ ). See Table 1 for values. Magnification is approximately $40 \times$.

$30 \mathrm{~min}$ at $48^{\circ} \mathrm{C}$ (cytoplasmic loop) and $52^{\circ} \mathrm{C}$ (C-terminus), and an extension step of $2 \mathrm{~h}$ at $68^{\circ} \mathrm{C}$. RT-PCR products were then separated on $2 \%(\mathrm{w} / \mathrm{v})$ low melting temperature agarose gels by electrophoresis at $100 \mathrm{~V}$ for $1 \mathrm{~h}$. The gels were then stained with ethidium bromide, and photographed using an AlphaEase Digital Imaging and Analysis System (Alpha Innotech Corporation, San Leandro, CA, USA). 

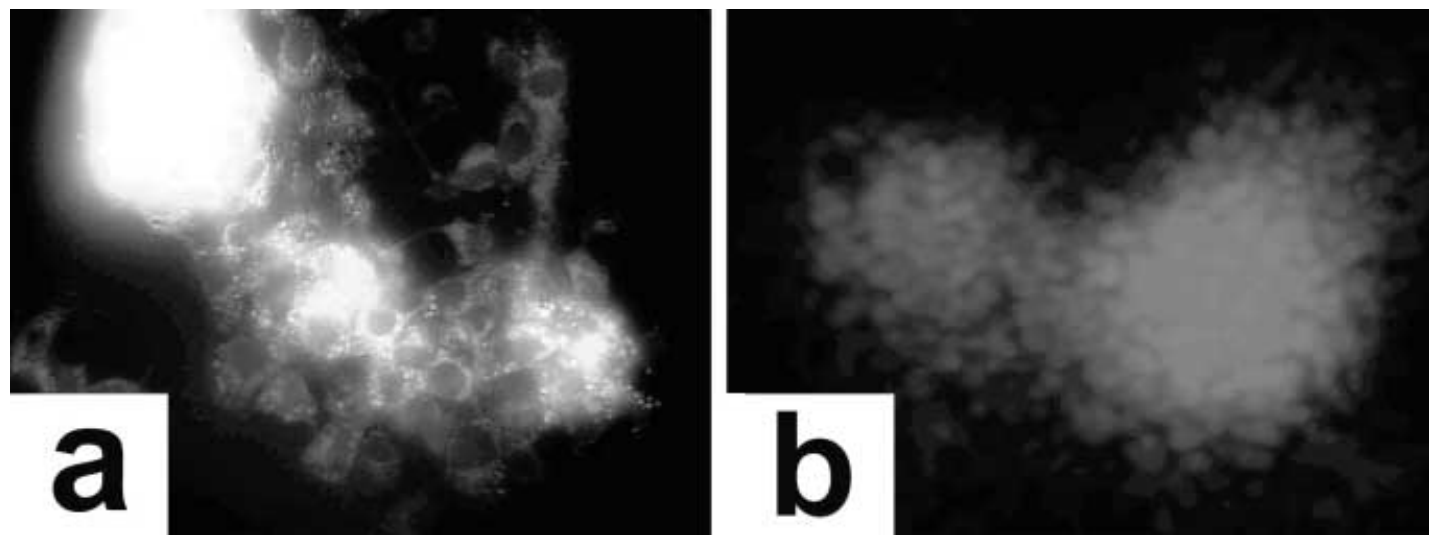

FIGURE 2. Immunocytochemical labeling of Cx32 gap junctions in FRTL-5 follicular cultures. Shown is a representative follicle from pass 9 cultures (panel a) which express a high level of Cx32 plasma membrane assembled gap junctions. In contrast, no punctate immunofluorescence was detected in the pass 20 FRTL-5 cells (panel b). The low level of fluorescence seen in panel b is equivalent to non-specific binding (data not shown). Images captured at $40 \times$ magnification.

\section{DNA purification and sequencing}

The designated bands from the RT-PCR gels were cut and purified using Qiaex II Gel Extraction Kit (Qiagen, Valencia, CA, USA). The cut bands were melted in a mixture of $400 \mu \mathrm{l}$ QX1 buffer and $15 \mu \mathrm{l}$ Qiaex II beads at $50{ }^{\circ} \mathrm{C}$ for $15 \mathrm{~min}$. After centrifugation at 14000 r.p.m. for 30 s, the pellets were washed once in QX1 buffer to remove any remaining agarose, then twice to remove residual salt contaminants. After air-drying for $2 \mathrm{~h}$ at room temperature, the pellets were eluted in $10 \mathrm{mM}$ Tris and the DNA supernatants were sent to the Center of Molecular Biology and Gene Therapy (Loma Linda University) for sequencing.

\section{BLAST alignment}

To determine if the RT-PCR products corresponded to the expected regions, the resulting DNA sequences were aligned with the known rat sequence database from the National Center for Biotechnology Information web site (www.ncbi.nlm.gov), using the BLAST (Basic Local Alignment Search Tool) program.

\section{Karyotyping}

Metaphase chromosome spreads from FRTL-5 cells were prepared by first treating the cells with $0.6 \mu \mathrm{g} / \mathrm{ml}$ colcemid for $24 \mathrm{~h}$ at $37^{\circ} \mathrm{C}$ in $5 \% \mathrm{CO}_{2}$.
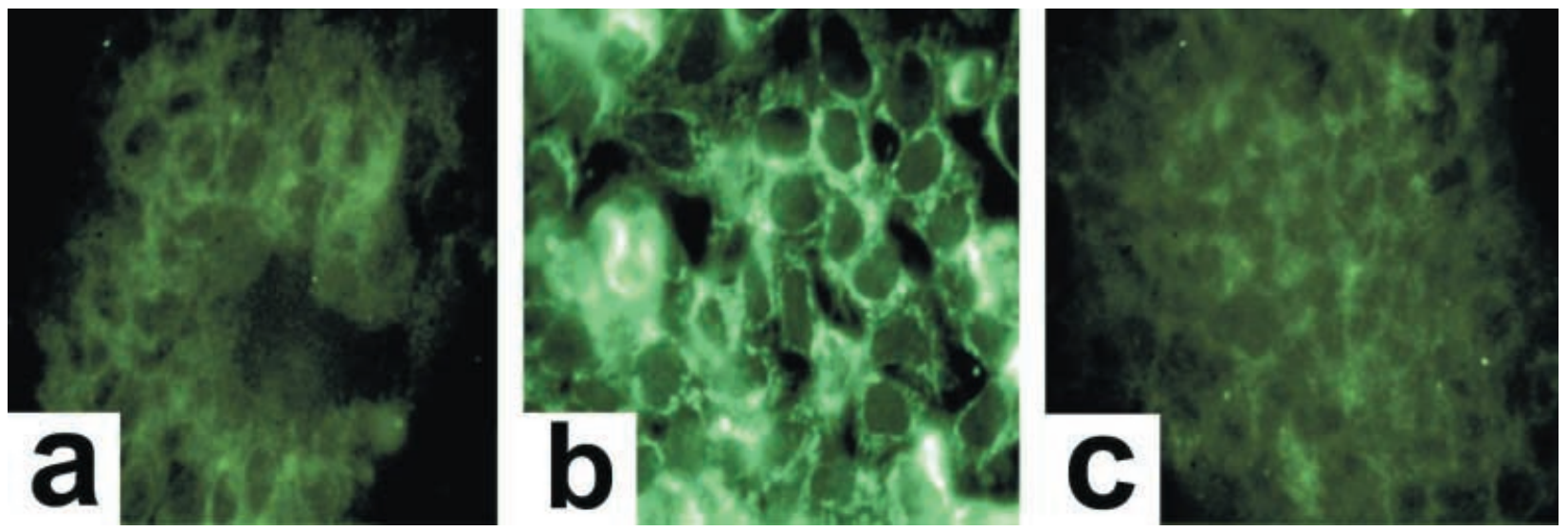

FIGURE 3. Immunophenotyping of connexin expression in FRTL-5 cells. Fixed FRTL-5 follicular cryosections from pass 12 cultures were incubated with anti-Cx43 (panel a), anti-Cx32 (panel b), and anti-Cx26 (panel c) and FITC-conjugated secondary antibody. There was no detectable $\mathrm{Cx} 43$ or $\mathrm{Cx} 26$, however $\mathrm{Cx} 32$ was expressed at a high level located in the lateral contacting surfaces. Magnification is approximately $100 \times$. 
After the colcemid treatment, the cells were lifted from the flasks by trypsinization and centrifuged (1500 r.p.m., $10 \mathrm{~min}$ ), washed once with medium and resuspended with continual mixing in $5 \mathrm{ml} \mathrm{KCl}$ $\left(0.55 \mathrm{~g} / 100 \mathrm{ml} \mathrm{H}_{2} \mathrm{O}\right)$. The cells were incubated for 30 min in the salt solution $\left(25^{\circ} \mathrm{C}\right)$ and then $3 \mathrm{ml}$ fixative (methanol:acetic acid, $3: 1 \mathrm{v} / \mathrm{v}$ ) were added and the samples left undisturbed for $12 \mathrm{~min}$. When this incubation was complete, the cells were centrifuged and resuspended in $10 \mathrm{ml}$ fixative and left undisturbed for 30 min (Oshimura \& Barrett 1986). Spreads were made by the drop-wise application of the samples onto clean, pre-labeled microscope slides. The slides were allowed to dry prior to staining with Giemsa $(0 \cdot 4 \%)$ and covered with glass coverslips using Permount (Fisher Scientific).

\section{MTS assay for cell proliferation and growth rate}

The growth rate of various passages of FRTL-5 cells was determined using the CellTiter 96 AQ aqueous one solution proliferation assay from Promega (Madison, WI, USA). This colorimetric method determines the number of viable cells by their ability to bio-reduce a novel tetrazolium compound (3-(4,5-dimethylthiazol-2-yl)-5-(3carboxymethoxyphenyl)-2H-tetrazolium, inner salt; MTS) and an electron-coupling reagent (phenazine ethosulfate; PES). PES has enhanced chemical stability, which allows it to be combined with MTS to form a stable, colored formazan, a product soluble in tissue culture medium. Cells were resuspended at $2 \times 10^{5} / \mathrm{ml}$ and $100 \mu \mathrm{l}$ aliquots of 2 -fold serially diluted samples (eight replicates per sample) were plated in 96-well microtiter plates. The time course study was conducted over $72 \mathrm{~h}$ with samples taken at various time intervals. At the desired time, $20 \mu \mathrm{l}$ MTS were added to each well and the plate was returned to the incubator. After $3 \mathrm{~h}, 100 \mu \mathrm{l}$ supernatant were transferred to a clean 96-well plate(s) and read at $490 \mathrm{~nm}$ wavelength in a Bio-Rad microplate spectrophotometer. The quantity of formazan product was measured by the amount of $490 \mathrm{~nm}$ absorbance, which was directly proportional to the number of living cells in the culture. The cell growth rates were calculated based on standard curves using the $0 \mathrm{~h}$ time point reading from a known concentration of cells.

\section{Thyroxine ELISA}

An ELISA was used to determine the amount of $\mathrm{T}_{4}$ released into the supernatant of FRTL-5 cultures from differing passage numbers. The quantitative measurements of $\mathrm{T}_{4}$ released were performed using a competitive, horseradish peroxidase-based, rat-specific ELISA purchased from Endocrine Technologies, Inc. (Newark, CA, USA). Briefly, established follicular cultures $(<80 \%$ confluent $)$ in six-well plates that were at least $24 \mathrm{~h}$ post medium replacement were given $1 \mathrm{nM} \mathrm{NaI}$ prior to harvesting the supernatant; in the $\mathrm{Cx} 32$ downregulation experiments $3 \mathrm{mM}$ heptanol was added $1 \mathrm{~h}$ prior to adding NaI. Several incubation periods were tested and the maximum $\mathrm{T}_{4}$ production was detected $6 \mathrm{~h}$ after the addition of NaI. Freezing also reduced the detectable levels of $\mathrm{T}_{4}$. Therefore, the supernatants were centrifuged to remove any non-adherent cells and/or debris and tested immediately (e.g. without prior freezing). Replicates of $100 \mu \mathrm{l}$ aliquots were mixed with a constant amount of peroxidase-conjugated $\mathrm{T}_{4}$, and incubated in microtiter wells coated with anti-rat $\mathrm{T}_{4}$ for $2 \mathrm{~h}$ at $22{ }^{\circ} \mathrm{C}$, followed by washing with PBS containing $0.05 \%$ Tween-20 (Fisher Scientific, Tustin, CA, USA). After washing, 3,3',5,5'-tetramethyl benzidene (TMB) substrate was added to all wells, color development was complete within $20 \mathrm{~min}$ and the plates were read at $450 \mathrm{~nm}$ on an automated plate reader (Model Fluorite 1000, Dynex Technologies, Inc., Chantilly, VA, USA) equipped with Revelation software version $3 \cdot 0$. The intensity of the color formed was proportional to the amount of enzyme present and was inversely related to the amount of unlabeled $\mathrm{T}_{4}$ in the sample. Complete cell medium alone was used in the blank wells. A series of $\mathrm{T}_{4}$ standards assayed in the same way was used to construct a standard curve from which the concentrations of $T_{4}$ in the test supernatants were interpolated.

Later passage cultures produced fewer follicles per equivalent starting cell densities, so we normalized $\mathrm{T}_{4}$ production per number of follicles in the cultures. Follicle counts were performed as previously described in Green et al. (2001). Briefly, plates/wells from which the supernatants were harvested were fixed with methanol:acetic acid $(3: 1 \mathrm{v} / \mathrm{v})$ for $15 \mathrm{~min}$ at room temperature followed by crystal violet staining. Counting was performed using an Alpha Innotech image processing system with trans-illumination. The machine was calibrated and manually adjusted for the size threshold, which was confirmed by visual inspection. The size threshold was set to exclude any follicle or cell aggregate less than $100 \mu \mathrm{m}$ in diameter. The automated counts were checked for precision by random sampling and comparison with manual counts. The precision limit was consistently within $5-7 \%$. 


\section{Statistical analysis}

Comparisons between early and late passage cells or samples were determined by Student's $t$-test. Proportional differences in the dye transfer experiments were judged for significance by Chi-squared analysis. $P<0.5$ was considered the limit for statistical significance.

\section{RESULTS}

\section{Gap junction-mediated cell-to-cell communication}

When monolayer FRTL-5 cells were microinjected with Lucifer Yellow dye, a fluorescent tracer used to judge cell-to-cell communication by measuring the degree of dye transfer between contiguous neighboring cells, we found that they were uncoupled. The contacting, monolayer FRTL-5 cells transferred dye from the injected cell to a primary contacting cell in less than $2 \%$ of trial injections (Table 1). This lack of cell-to-cell communication, as judged by failure to transfer dye, did not change with age or passage number as long as the cells remained in a monolayer configuration (Fig. 1a and $b)$.

When FRTL-5 cells established as follicles were microinjected, they transferred dye from the injected cell to second- and third-order neighboring cells and beyond within 2 min of injection (Table 1, Fig. 1c and d). This intercellular communication was manifest in follicular cultures that had been passed fewer than 15 times. Once the cultures had been maintained past passage 15 they only occasionally transferred dye to adjacent (first order) neighboring cells (Fig. 1e and f). Chi-squared analysis was performed comparing the proportional differences between each of the morphological states and dye transfer categories. The ability of early versus late follicles to transfer microinjected dye was significantly different $(P<0 \cdot 001)$, as were early follicles to monolayers $(P<0 \cdot 001)$.

\section{Immunophenotyping of connexin expression}

The presence of plasma membrane assembled gap junctions is a prerequisite to electrically coupled intercellular communication (Unwin \& Zampighi 1980). FRTL-5 cells from early $(<12)$ and late $(>15)$ passages established as monolayers were immuno-labeled with anti-Cx43, Cx32 and $\mathrm{Cx} 26$ to determine whether proteins corresponding to the rat thyroid Cxs were expressed. The immuno-labeling revealed that none of the three connexins were expressed in monolayer FRTL-5 cells (data not shown). Cx32 was detectable as a plasma membrane punctate structure in follicular cultures, but only in those passed fewer than 15 times (Fig. 2). The follicular organization did not allow for a definitive intracellular location of $\mathrm{Cx} 32$ to be visualized, so cryostat sections of follicles were immuno-labeled for the three connexins. A representative composite is shown in Fig. 3. Again $\mathrm{Cx} 43$ and $\mathrm{Cx} 26$ were not evident; however, $\mathrm{Cx} 32$ protein containing gap junctions were present in the lateral membranes of these passage 12 FRTL-5 cells. Later passage FRTL-5 follicle sections did not label with any of the anti-connexin antibodies/antisera (data not shown).

\section{Western blot analyses for $\mathrm{Cx} 32$ protein}

Connexin proteins can be expressed without being trafficked and/or assembled correctly in the plasma membrane at points of cell-to-cell contact (Green et al. 1995a, 1996, 1997, Deschenes et al. 1997). Therefore we fractionated the cell lysates and extracted protein from various passage number FRTL-5 cultures in an attempt to understand the loss of $\mathrm{C} \times 32$ protein expression in the later passages. Total, membrane and cytosolic components were separated, immunoprecipitated and electrophoresed in parallel. A representative Western blot is shown in Fig. 4. $\mathrm{Cx} 32$ protein expression was detected in early passage cultures (pass 5 and 12). Although the membrane-enriched fraction from pass 12 cultures was reduced in the amount of $\mathrm{Cx} 32$ detected, no $\mathrm{Cx} 32$ was detected in later passage cultures (pass 18 and 25). Thus the later passage cells were not expressing immuno-detectable Cx32. Total lysates of liver and lung tissue were run in parallel for positive and negative controls respectively.

\section{Northern blot and RT-PCR analyses for connexin mRNA}

To corroborate the functional (dye transfer) and immunocytochemical data we investigated transcriptional expression of $\mathrm{Cx} 32$ using isolated total RNA from passage 12 FRTL-5 cultures. The RNA was electrophoresed and the Northern blots hybridized with connexin specific cDNAs. The blots revealed that $\mathrm{Cx} 32$ RNA was present, however no Cx43 or Cx26 mRNAs were detected in the pass 12 FRTL-5 cells (data not shown).

The connexins are a family of related proteins that are highly conserved, single copy genes (Willecke et al. 1990). Cx32 is located on the X chromosome, and the gene has two exons, one in the $5^{\prime}$ untranslated region and the other, exon 2, 


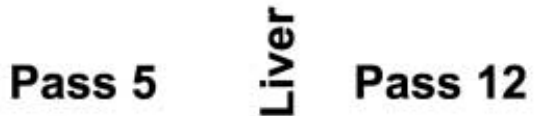

$35.7 \mathrm{~K} \rightarrow$

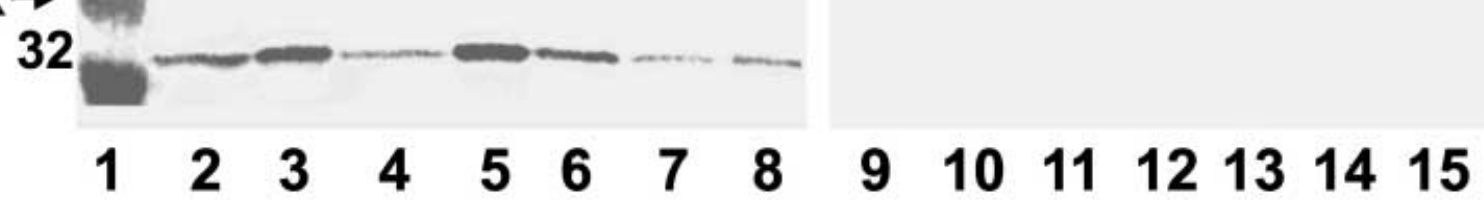

FIGURE 4. Western blot analyses for Cx32 protein expression in FRTL-5 cells. Different passes of FRTL-5 cells were lysed and fractionated by ultra-centrifugation. Total protein lysate (lanes 2, 6, 9, 12) cytosolic (lanes 3, 7, 10, 13) and membrane (lanes $4,8,11,14$ ) enriched fractions were immunoprecipitated with anti-Cx32 antibody, followed by Western blot analyses. Cx32 protein expression was detected in early cultures (passes 5 and 12), whereas no Cx32 was detected in later passage cultures (passes 18 and 25). Molecular weight markers are in lane 1. Total protein from liver (lane 5) and lung (lane 15) tissue were included as positive and negative controls respectively.

contains the entire, uninterrupted coding sequence (Miller et al. 1988). The Cx32 protein is 283 amino acids in length, and has a cytoplasmic aminoterminus, four transmembrane regions, two extracellular loops, a cytoplasmic loop and a cytoplasmic carboxyl-tail region (Dahl et al. 1987). The most variability between family members occurs in the cytoplasmic loop and carboxyl-tail regions. To better understand the passage-dependent loss of Cx32 expression we designed primers for these unique regions of the rat $\mathrm{Cx} 32$ molecule for use in an RT-PCR assay. The RT-PCR DNA products corresponding to the cytoplasmic loop and the carboxyl-terminal region are shown in Fig. 5. Primary rat thyroid and early pass FRTL-5 cultured cells (pass 5 and 14) yielded bands that corresponded to the 81 bases of the cytoplasmic loop and 190 bases of the carboxyl-terminal region of rat Cx32 DNA. FRTL-5 cells from late passes produced a band only at the cytoplasmic loop position with no product at the C-terminal fragment position (Fig. 5).

To determine whether the electrophoresed bands were equivalent to the known rat $\mathrm{Cx} 32$ sequences, the FRTL-5 products were aligned using a BLAST search from the www.ncbi.nih.gov web site (ref/NM 017251·1/Rattus norvegicus gap junction membrane channel protein beta-1 (Gjb1), mRNA length $=1485$ nucleotides, coding region 32-881). The results are shown in Fig. 6. The primary thyroid and FRTL-5 cells from early passes produced cytoplasmic loop sequences that exactly matched the known rat sequence (base positions 343-424). The carboxyl-terminal sequence bases 23-213 of the RT-PCR product almost exactly matched the known rat sequence, nucleotide

www.endocrinology.org positions 705-895. The only exception was a transversion of a $\mathrm{G}$ to a $\mathrm{C}$ at our position 164 , which corresponded to known rat $\mathrm{Cx} 32$ sequence position base 850 , amino acid number 273 . This change had no net effect as both codons, CUC and CUG, specify leucine (Fig. 6B).

The later passage FRTL-5 cells had a single base deletion at position 36 of the 81 base-long DNA products of the cytoplasmic loop region (corresponding to base position 378 of the published sequence, Fig. 6A). The single base deletion altered the protein sequence starting at amino acid 116, where the normally occurring histidine was changed to a proline (Fig. 6A). The next four amino acids were changed from leucine, glutamic acid, glutamic acid and valine, to tryptophan, lysine, arginine and stop (UAA, ochre). The $\mathrm{Cx} 32$ protein stops at amino acid 120, which occurs at the site where the cytoplasmic loop starts its ascent toward the third transmembrane region. This premature truncation resulted in a protein that is less than half the length of the normal $\mathrm{Cx} 32$ protein. This finding is consistent with the immunocytochemical data. The lack of a RT-PCR product corresponding to the carboxyl-terminus in the later passage cultures indicates that the mRNA for $\mathrm{Cx} 32$ is also truncated. This truncation explains the failure to detect the mRNA for Cx32 by Northern blot analysis due to the significantly reduced strength of the hybridization signal.

\section{FRTL-5 cell karyotype}

The ubiquitous expression of connexin proteins, especially $\mathrm{Cx} 43$ in continuous passage cell lines suggested that there may be genetic or epigenetic 


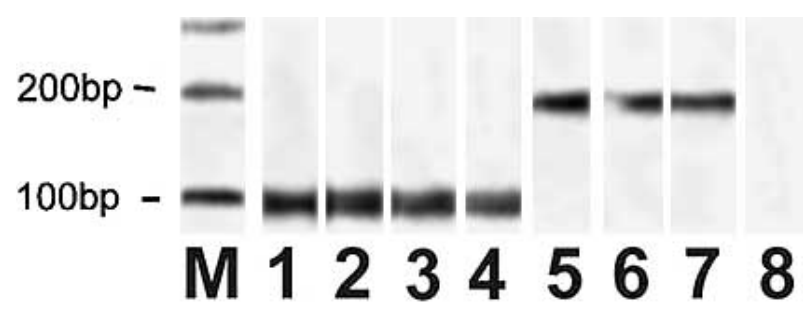

FIgURE 5. RT-PCR analyses of Cx32 mRNA. Specific primers were made to the $\mathrm{Cx} 32$ cytoplasmic loop region (resulting products in lanes 1-4), and the C-terminal region (products in lanes 5-8). DNA products from primary rat thyroid RNA are in lanes 1 and 5, FRTL-5 pass 5 in lanes 2 and 6 , FRTL-5 pass 14 in lanes 3 and 7 , and FRTL-5 pass 25 in lanes 4 and 8 . Bands corresponding to the cytoplasmic loop position (approximately $100 \mathrm{bp}$ ) were detected in all samples loaded, whereas bands corresponding to the C-terminal position (approximately $200 \mathrm{bp}$ ) were present in all except pass 25 , the latest FRTL-5 passage tested.

abnormalities that could account for the lack of Cx43 and Cx26 expression in FRTL-5 cells. Several reports describe FRTL-5 cells as being diploid (Mulcahy et al. 1985, Bellur et al. 1990, Dai et al. 1992, Backeljauw et al. 1993). When we inquired in late 1996 whether the ATCC had a record of the FRTL-5 karyotype they did not. Chromosome spreads from pass 3-12 of the FRTL-5 cell cultures revealed a complete tetraploid karyotype; a typical spread is shown in Fig. 7A. These spreads were consistently composed of 88 chromosomes which was four times the 22 haploid chromosomes normally found in rat cells ( $n=50$ spreads). When late passage cultures (passes 18-22) were evaluated, they were found to be tetraploid plus $3 \pm 1$ extra chromosomes ( $n=50$ spreads). The extra chromosomes found in these cultured cells were not always the same ones based on size and centromere position. Collectively there were no visible translocations, breaks or obvious losses of chromosomes or chromatids in any of the FRTL-5 cultures tested (Fig. 7B).

\section{Morphologic changes as a function of FRTL-5 passage number}

Under early passage conditions, FRTL-5 cells exist primarily as discrete follicles. However, as they are repeatedly passed they began to change. Cultures of FRTL-5 cells that are overgrown, or at a medium density but from a late pass number showed a monolayer 'skirting' that spreads from beneath the follicles. The follicles also become flatter, as if their lumenal spaces were reduced in volume (Fig. 8). The shape of cells making up monolayer areas are flatter, larger and more cuboidal than cells organized, or participating, in follicles.

\section{Growth rate as a function of FRTL-5 passage number}

The reported average cell division time for FRTL-5 cells varies greatly in the literature with the most common doubling time reported as $30-36 \mathrm{~h}$ (Brosing et al. 1989, Huber et al. 1990, Pekary et al. 1995, 1997, Statuto et al. 1997). From experience with FRTL-5 cells it was clear that older (higher passage number) cultures established and grew faster than early passes. To measure this, FRTL-5 cells of various passage numbers were compared (Fig. 9). We found that FRTL-5 cells from passes 5-8 had an average division time of $49 \pm 1 \mathrm{~h}$, and later passes $20-25$ had an average doubling time of $28 \pm 3 \mathrm{~h}$. Intermediate passage numbered cultures had intermediate growth rates (Table 2).

\section{Thyroxine release as a function of FRTL-5 passage number}

Thyroxine levels were measured in early and late FRTL-5 cultures to determine whether the presence or absence of competent $\mathrm{Cx} 32$ gap junctions correlated with altered output of $\mathrm{T}_{4}$. As an additional way to assess the contribution of $\mathrm{Cx} 32$ gap junctions to $\mathrm{T}_{4}$ release, we treated early passage follicular cultures with heptanol which binds to

FIGURE 6. RT-PCR product sequencing and alignment. Shown are the sequences from the 81 bp band of FRTL-5 pass 25 (panel A) and the $190 \mathrm{bp}$ band of FRTL-5 pass 5 (panel B) that were purified and sequenced. The RT-PCR products were BLAST aligned with the known rat $\mathrm{Cx} 32$ (beta 1 protein) nucleotide sequence. The results revealed that the product from pass 25 cells corresponded to 80 of the 81 nucleotides of the known sequence positions $343-424$ in the cytoplasmic loop region of rat $\mathrm{Cx} 32$. The missing base was a deletion at position 378 in the published sequence, our product number 36. The deleted 'a' caused a frame shift which altered the amino acid sequence at position 116 where the normally produced histidine (CAC) became a proline (CCC). All the FRTL-5 cultures produced RT-PCR products that had a transversion from a $\mathrm{G}$ to a $\mathrm{C}$ in the $\mathrm{C}$-terminus (panel $\mathrm{B}$ ). This transversion did not change the amino acid sequence, both CUG and CUC code for leucine. The dotted line (....) in panel B indicates bases that are not shown to conserve space; the dashed line (----) indicates that the query sequence identically matched the subject sequence; square brackets, [ ], indicate codons of interest; and parentheses, ( ), indicate translation stop codons. The numbers at the start and stop of the lines indicate the DNA, RNA or amino acid numbers of the sequences investigated. 


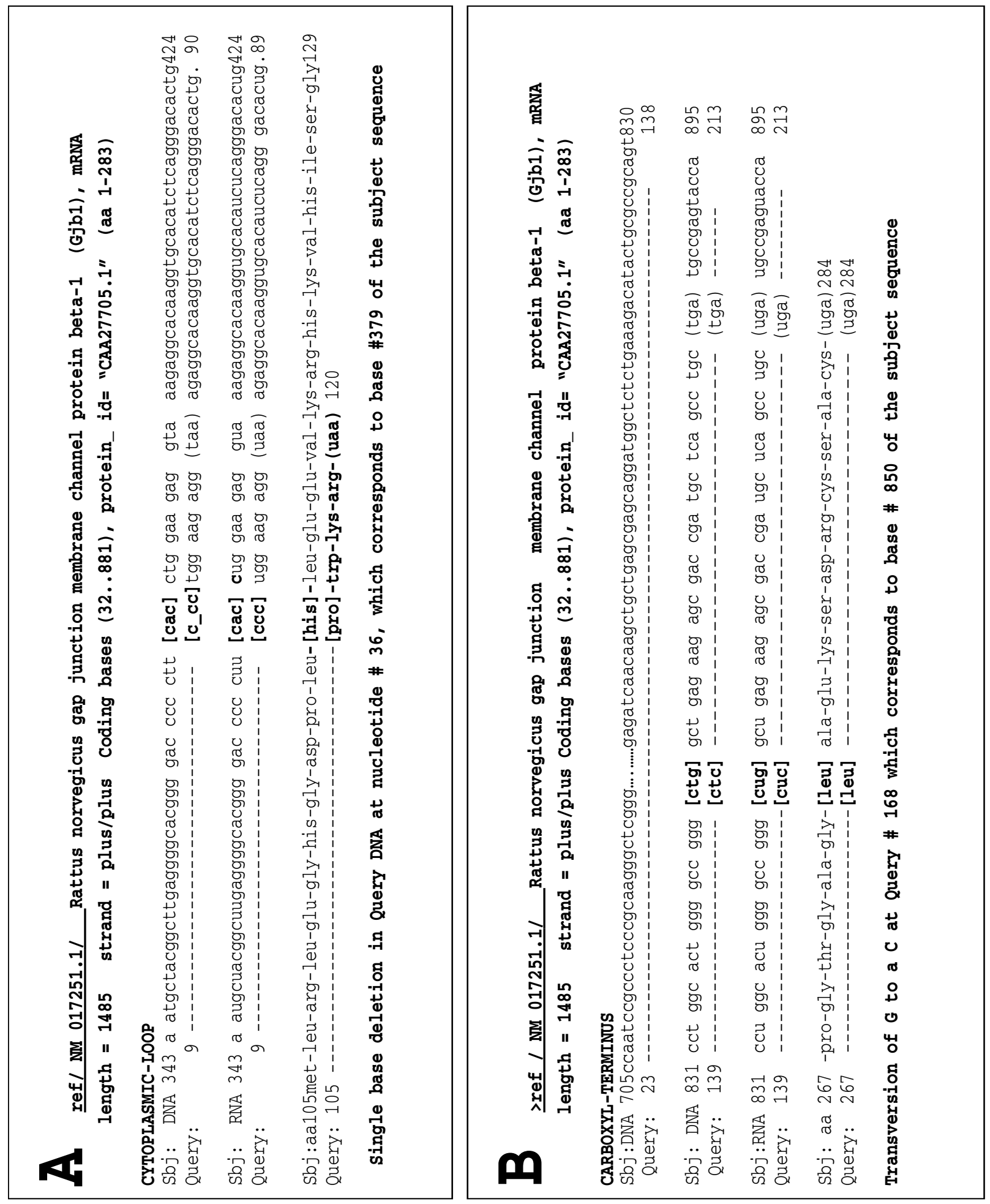




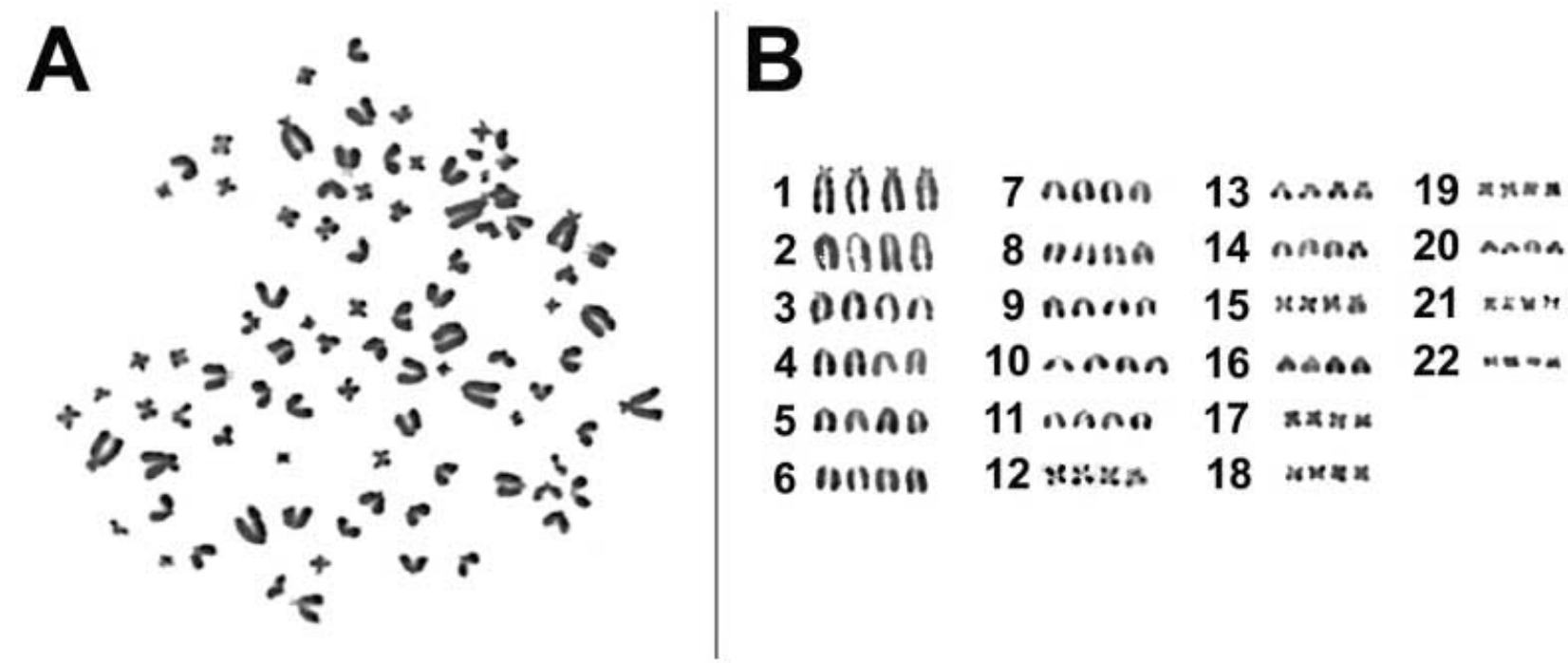

FIGURE 7. FRTL-5 cell karyotype. Chromosome spreads were prepared from various passage FRTL-5 cultures. Panel A shows a typical chromosome spread from early passage cultures (passes 3-15) of FRTL-5 cells. When arranged by size and centromere position they were found to be fully tetraploid with four times 22 chromosomes for a total of 88 (panel B). Later passage cultures (passes 15-22) were typically tetraploid plus two or three extra chromosomes (data not shown).

lipid cholesterol causing a conformation change in the connexins that results in the closing of the junctions (Bastiaanse et al. 1993). Closed junctions are removed from the plasma membrane and degraded (Jordan et al. 2001). New Cx32 protein is made and gap junctions are reassembled. The total time from addition of heptanol to re-established communication is approximately $6 \mathrm{~h}$. Thyroxine levels were measured using a colorimetric ratspecific competitive ELISA. Because later passage cultures produced fewer follicles under conditions of equivalent starting cell densities, we normalized the level of $\mathrm{T}_{4}$ released on a per follicle basis. Early

TABLE 2. Growth rate in FRTL-5 cells as a function of passage number

\begin{tabular}{|c|c|c|c|}
\hline & $\begin{array}{l}\text { No. of } \\
\text { divisions/ } \\
24 \mathrm{~h}\end{array}$ & $\begin{array}{l}\text { Doubling } \\
\text { time (h) }\end{array}$ & $n^{\mathrm{a}}$ \\
\hline Pass $6^{\mathrm{b}}$ & $0 \cdot 48$ & $49 \pm 1$ & 3 \\
\hline Pass 9 & 0.52 & $46 \pm 2$ & 2 \\
\hline Pass 13 & $0 \cdot 55$ & $44 \pm 1$ & 3 \\
\hline Pass 17 & $0 \cdot 67$ & $36 \pm 2$ & 3 \\
\hline Pass 20 & $0 \cdot 86$ & $28 \pm 3$ & 3 \\
\hline Pass 25 & 0.96 & $25 \pm 2$ & 2 \\
\hline
\end{tabular}

${ }^{\mathrm{a}}$ Number of experiments (eight replicates per experiment).

bNumber of times FRTL-5 cells were passaged in our laboratory. cultures treated for $6 \mathrm{~h}$ with $\mathrm{NaI}$ released to the supernatant an average of $5 \cdot 27 \pm 0.33 \mathrm{ng} / \mathrm{ml} \mathrm{T}_{4}$ per 100 follicles, early passage cultures treated with heptanol released an average of $3 \cdot 91 \pm 0 \cdot 55$, whereas later passage cultures released $3.77 \pm 0.45 \mathrm{ng} / \mathrm{ml} \mathrm{T}_{4}$ per 100 follicles. Treatment of later passage follicular cultures with heptanol did not significantly alter the level of $\mathrm{T}_{4}$ released. The results for the $\mathrm{T}_{4}$ data are compiled in Table 3 . The difference in $\mathrm{T}_{4}$ release between $\mathrm{Cx} 32$ competent and $\mathrm{Cx} 32$ incompetent follicular cultures was $27 \%$ and was statistically significant $(P<0.0001)$ and similar to the drop in $\mathrm{T}_{4}$ levels in hypothyroid rats (35\% decrease reported by Green et al. 1996). When tested at $24 \mathrm{~h}$, the levels of $\mathrm{T}_{4}$ were approximately $60 \%$ less than detected in the same flasks at $6 \mathrm{~h}$. Freezing also reduced the detectable levels of $\mathrm{T}_{4}$.

Control conditions for these experiments included $\mathrm{T}_{4}$ release in the absence of iodide, and from cell monolayers versus cells organized as follicles. Thyroxine was not detected in supernatants from monolayers of early or late FRTL-5 passages, with or without iodide. Early and late FRTL-5 follicles produced $\mathrm{T}_{4}$ at very low levels when cultured in the absence of iodide. The early FRTL-5 follicles released $1 \cdot 13 \pm 0 \cdot 21 \mathrm{ng} / \mathrm{ml} \mathrm{T}_{4}$ per 100 follicles and the late FRTL-5 follicles released $0 \cdot 22 \pm$ $0.04 \mathrm{ng} / \mathrm{ml}_{4}$ per 100 follicles into the culture supernatant (Table 3 ). 

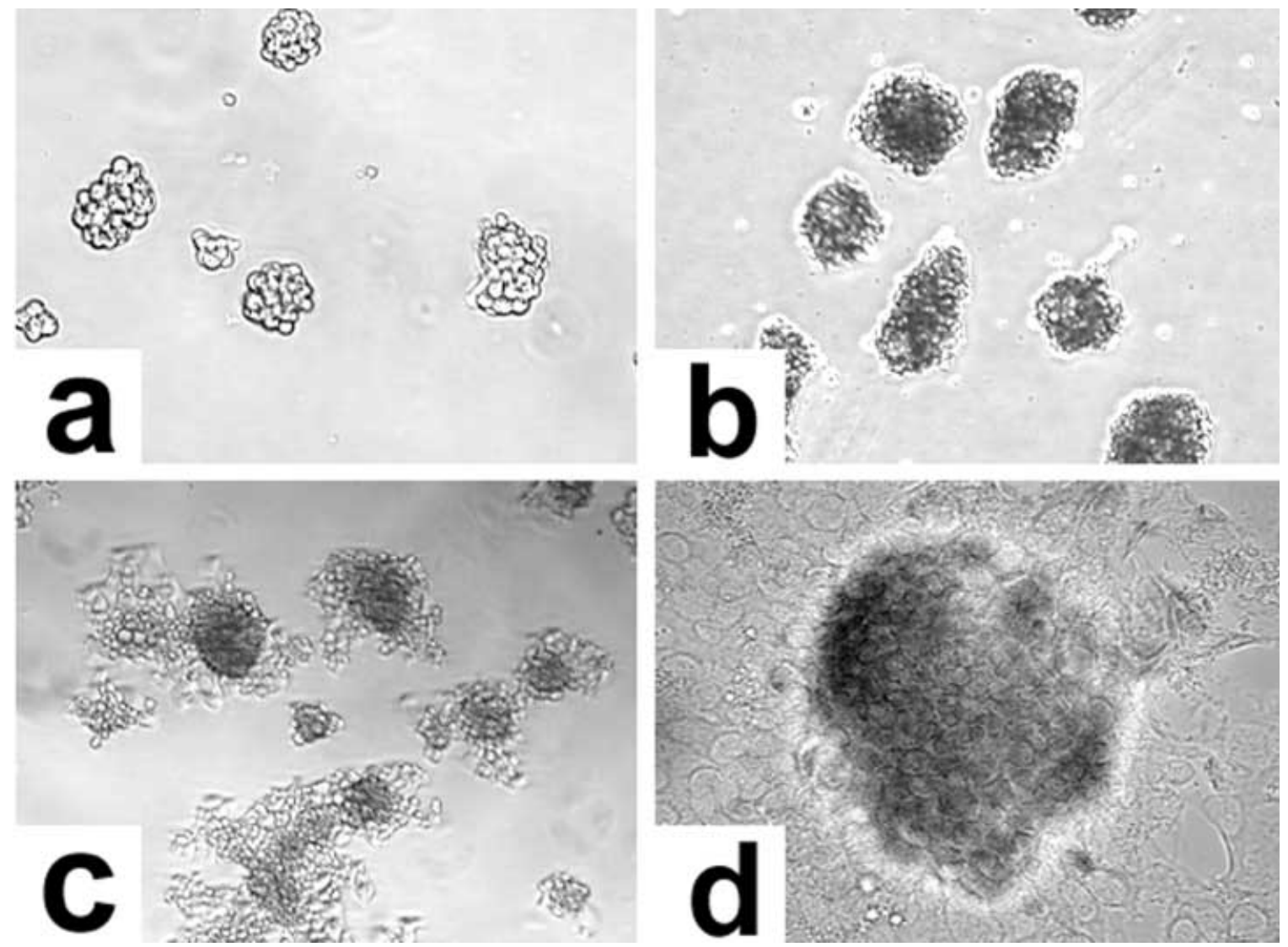

FIGURE 8. Morphologic changes in FRTL-5 cells as a function of passage number. When maintained normally, early passage FRTL-5 cultures organized into discrete follicles usually surrounded by cell-free areas. Shown is a pass 6 culture photographed on day 5 (panel a) and on day 11 (panel b). When the cultures are left past the normal passage time (panel $\mathrm{c}$ is at 13 days), or are derived from later passages (shown is pass 19) they develop a monolayer 'skirting' that spreads from beneath the follicles (panel d). Note also the flattened appearance of the follicles in the later passage cultures, which suggests a reduced lumenal volume (panel d). Capture magnification of panels a-c was $10 \times$ and panel d $40 \times$.

\section{DISCUSSION}

Our use of FRTL-5 cells has been as a model system in which we have developed protocols for use with primary thyroid cultures. As such we have kept careful passage records utilizing only early passages for the retention of normal thyrocyte characteristics. The only significant culture condition change we introduced was to use DMEM:F12 instead of F12 medium. Numerous reports by others ascribed properties to FRTL-5 cells that differed from what we observed. This prompted us to continue expanding the cultures to determine whether age-related changes or conditional differences could explain the discrepant results.

Follicular cultures of FRTL-5 cells are coupled by Cx32-type gap junctions. They transfer Lucifer
Yellow dye from an injected cell to third-order neighboring contacts and beyond, and have discrete immuno-detectable punctate fluorescent plaques corresponding to $\mathrm{Cx} 32$ gap junctions at their lateral contacting plasma membrane surfaces. Intercellular communication via $\mathrm{Cx} 32$ expression was only manifest in cultures that were maintained as follicles and passed fewer than 15 times. Microinjection, immunocytochemistry, Western and Northern blot analysis confirmed that once cultures were passed more than 15 times they did not communicate, as determined by dye transfer, nor did they contain detectable $\mathrm{Cx} 32 \mathrm{mRNA}$ or protein.

To better understand this demarcation of $\mathrm{Cx} 32$ expression at passage 15 we used RT-PCR with primers generated to amplify the two most unique regions of the rat Cx32 DNA sequence (Paul 1986, Beyer et al. 1987, Zimmer et al. 1987, Miller et al. 


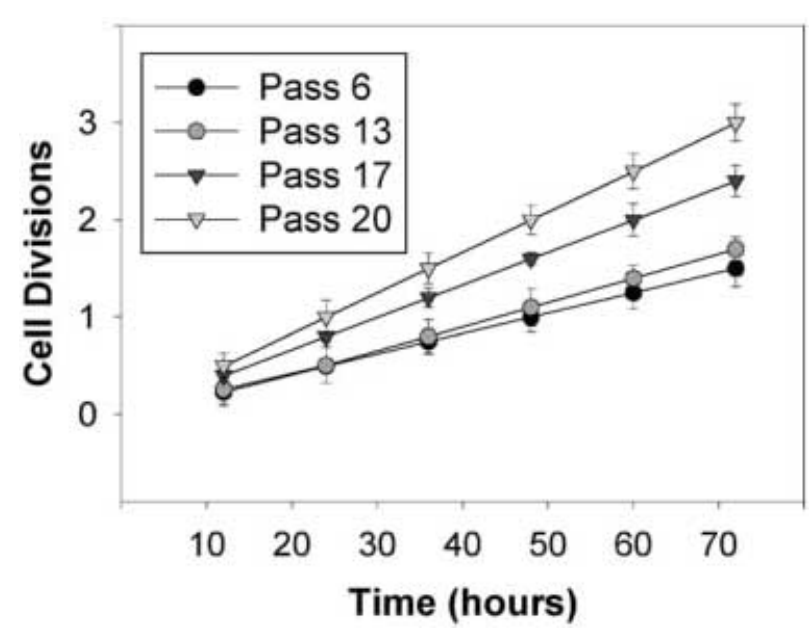

FIGURE 9. Growth rate as a function of FRTL-5 passage number. FRTL-5 cells from different passes $(6$, $13,17,20)$ are shown. The cells were seeded at $2 \times 10^{4}$ cells per well in 96 -well plates and titered by twofold serial dilution. At the indicated times, cell density was determined using bio-reduction of MTS. The graph represents the number of cell divisions versus time in hours for the various passage numbered cultures shown. Each symbol represents the mean of $24(=3 \times 8)$ replicate determinations \pm s.E. The resultant doubling times are shown here and the growth rate values listed in Table 2.

TABLE 3. Thyroxine release by FRTL-5 cells
1988). RT-PCR products from FRTL-5 RNA revealed that cultures past passage 15 had acquired a single base deletion in the middle of the cytoplasmic loop region and did not make an $\mathrm{R}$ T-PCR product corresponding to the C-terminus. This point deletion caused a frame shift that resulted in a translation stop signal four codons or 12 nucleotides downstream from the deleted base. This premature termination of the protein at amino acid 120 resulted in a failure to complete the remaining $60 \%$ of the molecule. Even with the frame shift that resulted in truncation of the protein, the entire sequence for the cytoplasmic loop region was made into a DNA product by RT-PCR. However, the lack of a sequence corresponding to the carboxyltail region suggests that the mRNA for $\mathrm{Cx} 32$ is also truncated. The message truncation must occur after the cytoplasmic loop between the third transmembrane region and start of the carboxyl-terminus. The altered protein sequence and loss of amino acids provides an obvious reason for the lack of antibody recognition, and failure to immuno-detect $\mathrm{Cx} 32$ protein in the later passage cultured cells. The failure of Northern blot analysis to detect Cx32 mRNA in the later passes is in agreement with a truncation. The loss of a significant portion of the

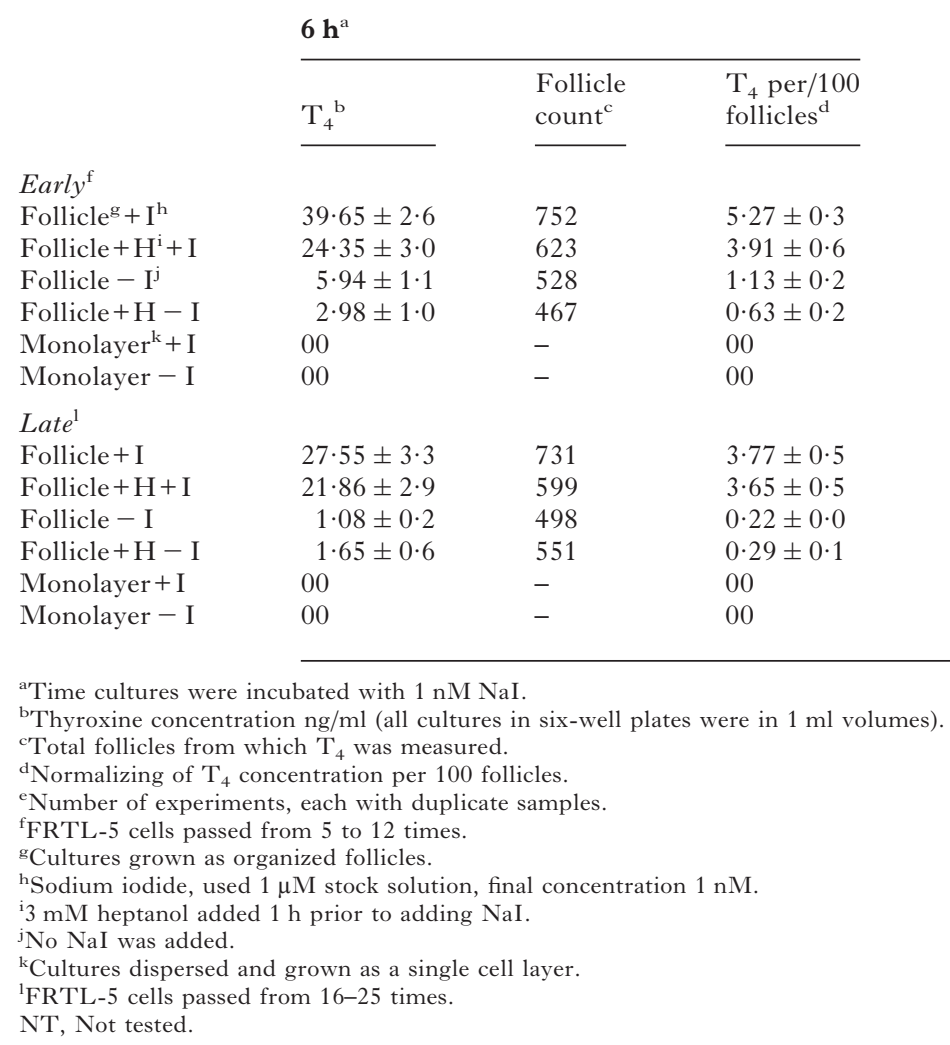

$24 \mathrm{~h}$

\begin{tabular}{|c|c|c|}
\hline $\mathrm{T}_{4}$ & $\begin{array}{l}\text { Follicle } \\
\text { count }\end{array}$ & $\begin{array}{l}\mathrm{T}_{4} \text { per } / 100 \\
\text { follicles }\end{array}$ \\
\hline $15 \cdot 86 \pm 0 \cdot 98$ & 752 & $2 \cdot 11 \pm 0 \cdot 13$ \\
\hline NT & - & - \\
\hline $2 \cdot 38 \pm 0 \cdot 49$ & 528 & $0 \cdot 45 \pm 0 \cdot 10$ \\
\hline NT & - & - \\
\hline 00 & - & 00 \\
\hline 00 & - & 00 \\
\hline
\end{tabular}

$\begin{array}{llll}11 \cdot 20 \pm 1 \cdot 3 & 731 & 1 \cdot 53 \pm 0 \cdot 18 & 4\end{array}$

$\begin{array}{llll}\text { NT } & - & - & 2\end{array}$

$\begin{array}{llll}00 & 498 & 00 & 3\end{array}$

$\begin{array}{llll}\text { NT } & - & - & 2\end{array}$

$\begin{array}{llll}00 & - & 00 & 2\end{array}$ 
mRNA would result in a reduction in the stringency required for hybridization and under normal conditions the smaller and reduced signal would be lost. This explains our failure to detect $\mathrm{Cx} 32$ mRNA in later passage cultures under conditions wherein primary thyroid and control liver gave strong hybridization signals.

There is a precedent for mutations in the $\mathrm{Cx} 32$ gene contributing to the pathogenesis of inherited demyelinating neuropathy in X-linked CharcotMarie-Tooth disease (Balice-Gordon et al. 1998, Scherer et al. 1999). Cx32 localizes to the paranodes and incisures of myelinating Schwann cells, where it is thought to participate in diffusion of ions and small molecules directly across the myelin sheaths (Scherer et al. 1999). The lack of functional Cx32 in this disease is associated with decreased nerve conduction velocities (Rouger et al. 1997), and non-functional $\mathrm{Cx} 32$ that is incorrectly trafficked accumulating in the cytosol causing toxicity (Deschenes et al. 1997, Scherer et al. 1999). There are numerous documented mutations in the coding region of the $\mathrm{Cx} 32$ gene, the most applicable examples include nonsense mutations in three different families that had transition mutations at amino acid 22 (arginine to stop) and transversion mutations at amino acid 186 (glutamate to stop) (Ionasescu et al. 1994), additional sites of point mutations are amino acid 15, 60, 63, 142, 208 and 215 (Fairweather et al. 1994, Ionasescu et al. 1994). Frame shift, point deletions and mutations have been identified in every domain of the Cx32 molecule and lead to incorrect trafficking, reduction and abrogation of $\mathrm{Cx} 32$ function in different families with this X-linked, inherited disease. These mutations provide evidence that each of the protein domains is important to the correct processing and function of Cx32 (Deschenes et al. 1997).

The finding of truncated $\mathrm{Cx} 32$ with age suggests that the observation by Statuto et al. (1997), that FRTL-5 cells do not express Cx32 mRNA or protein, could be due to the age or passage number of their cultures. We suggest that their cultures were past the equivalent of our passage 15 at the time of the study, perhaps because their original isolate may have been older. This supposition is consistent with the growth rate they report for their FRTL-5 cultures. It should also be noted that the hormone supplement somatostatin was eliminated from their culture medium. According to Ambesi-Impiombato et al. (1980), the presence of somatostatin was most important to cells plated at very low densities, and when absent the cells grew more slowly. They implied that under normal culture conditions the role for somatostatin was less critical, although recent studies suggest that

www.endocrinology.org
FRTL-5 cells can make somatostatin (Medina et al. 1999) and that somatostatin and TSH have opposing effects that act to balance the cell cycle regulating components leading to proliferation (Azuma et al. 1990, Medina et al. 2000).

Cx32 expression is transient in primary cells (Neveu et al. 1994) and rarely found in cell lines whether continuous passage or transformed. In fact, hepatocytes, which should express $\mathrm{Cx} 32$ as their dominant gap junction protein, when established in culture, quickly lose $\mathrm{Cx} 32$ and become $\mathrm{Cx} 43$ gap junction coupled cells (Neveu et al. 1995). Interestingly, Kojima et al. (1995) demonstrated that changing the medium and serum conditions induced the reappearance and long-term maintenance of $\mathrm{Cx} 32$ in adult rat hepatocytes. The retention of $\mathrm{Cx} 32$ by early passage FRTL-5 cells provides a unique opportunity for investigating the role of Cx32 and its contribution to normal thyrocyte properties.

When we purchased FRTL-5 cells we were focused on gap junctions and contact-dependent disturbances associated with inflammation in primary thyroid cultures. We assumed that their ability to transfer Lucifer Yellow dye to contacting neighboring cells was due to the ubiquitous expression of $\mathrm{Cx} 43$ type gap junctions. When FRTL-5 cells did not express $\mathrm{Cx} 43$ we conducted our first karyotypic examination of these cells to determine whether they had any genotype changes that could account for this loss. Our cultures in 1995 were fully tetraploid (modal number 88) as were cells from an original vial received from the ATCC (1992). Thus, the absence of Cx43 could not be explained by a large-scale loss of chromosomal DNA. However, any number of small gene mutations and/or altered regulatory mechanisms might explain its down-regulation as we found for Cx32.

In the original report by Ambesi-Impiombato et al. (1980) the FRTL-5 cells were checked and reported as having a diploid chromosome number. Since then, there have been several reports that FRTL-5 cells are diploid (Mulcahy et al. 1985, Bellur et al. 1990, Dai et al. 1992, Backeljauw et al. 1993). Most of these studies do not appear to have included a direct measurement of chromosome number, but rather reported a characteristic that had been associated with this fairly normal thyroid cell line. In 1998, Tasevski et al. reported that pass 14 FRTL-5 cells obtained from the ATCC were non-diploid with a modal number of 84 chromosomes (Tasevski et al. 1998). In that report fetal calf serum was used to grow the FRTL-5 cells. This would produce a set of cellular responses driven by the rich growth factor environment of fetal serum 
and preclude a direct comparison with cells grown in a more defined media. Under our culture conditions the tetraploid geneotype of FRTL-5 cells is consistent with normal cellular responses and state of thyroid differentiation, and suggests a balance of gene regulation and expression. Tetraploidy per se can be consistent with normal cell behavior and is supported by a report of a tetraploid species of rat (Gallardo et al. 1999). When later passage cultures of FRTL-5 cells were examined they were found to be aneuploid (tetraploid plus two or three extra chromosomes) and to have aberrant properties. The reason for this genomic instability is currently unknown.

An additional change that became evident with repeated passage was an increase in the degree of monolayer growth and subsequent reduction in the follicular content of the cultures. These tissue organization changes were coincident with the loss of functional $\mathrm{Cx} 32$, which supports a potential relationship between the loss of communication and the change in morphogenic appearance, as has been previously suggested (Munari-Silem et al. 1994). Of course, accompanying changes in adhesion properties and cytoskeletal components are also possible. This loss of functional tissue unit organization with age could explain reports that FRTL-5 cells do not form follicles (Zurzolo et al. 1991, Statuto et al. 1997, Tonoli et al. 2000) and implies that the cultures being used are well past passage 15 . Associated with these morphologic changes was a dramatic increase in growth rate of the older (higher pass number) cultures. Our early pass cultures divided on average every $49 \mathrm{~h}$, a value similar to primary thyroid cells (Christov et al. 1973, Green et al. 1996). Most often, the average division time reported ranged from 30 to $36 \mathrm{~h}$ (Brosing et al. 1989, Huber et al. 1990, Pekary et al. 1995, 1997, Statuto et al. 1997). From our study this would correspond to cultures that had been advanced beyond pass 17. Although passage number is strongly implicated, we cannot rule out the possibility that the medium and other conditional differences between laboratories could be responsible for some of the different properties evident at earlier passage numbers. An example of how the growth rate of FRTL-5 cells can be used as an indicator of passage number, and demonstrate the relationship of $\mathrm{Cx} 32$ expression to growth control is exemplified in the report by Statuto et al. (1997). They measured the wild-type division time for their FRTL-5 cells at $35 \mathrm{~h}$ and found that FRTL-5 cells did not express $\mathrm{Cx} 32$ at the mRNA or protein levels. According to our growth curves their cells would be at about passage 17 and would not be expressing full length $\mathrm{Cx} 32$. Interestingly, in their study they up-regulate $\mathrm{Cx} 32$ expression by transfection and found the division time was now extended to $50 \mathrm{~h}$. This protracted time per cell division with the re-introduction of competent $\mathrm{Cx} 32$ gap junctions parallels the properties of the $\mathrm{Cx} 32$ expressing FRTL-5 follicular cultures we defined as early (passes 3-12) and argues strongly for the casual link between $\mathrm{Cx} 32$ expression and the other phenotypic changes. This dramatic change in growth rate with the expression of $\mathrm{Cx} 32$ supports its potential role as a tumor suppressor (Kerbel 1995, Mehta et al. 1999, Yamasaki et al. 1999a,b) and underscores its importance in maintaining organized, functional thyroid cells.

To complete this investigation we assessed a normal property of functional thyroid follicles by measuring $\mathrm{T}_{4}$ release. The $27 \%$ difference in $\mathrm{T}_{4}$ release between early and later passage follicles is consistent with the idea that homotypic coupling between glandular epithelium increases the output of hormone, as was described in pancreatic islet cells by Meda (1989). In our case, coordinated follicular thyrocytes that are coupled by gap junctions have an increased output of thyroid hormone on a per follicle basis when compared with follicles that are no longer coupled by Cx32-type gap junctions. Support for this contention was obtained when heptanol treatment of early cultures (to close the channels) resulted in levels of $\mathrm{T}_{4}$ similar to late passage cultures that have a mutated, nonfunctional form of $\mathrm{Cx} 32$. Although other factors may be contributing to this reduction, a similar situation exists in primary thyrocytes isolated from sites of autoimmune thyroiditis wherein the thyroid specific gap junctions are produced but not trafficked correctly and so remain cytosolic (Green et al. 1995a, 1996, 1997). In these uncoupled primary thyroid follicles, the hypothyroidism is, in part, due to the lack of coordinated responses to TSH stimulation. In light of the mutations in $\mathrm{Cx} 32$ found in this study and those described for the X-linked Charcot-Marie-Tooth disease (Deschenes et al. 1997), the abnormal assembly of gap junctions in autoimmune thyroiditis should be revisited.

Collectively, FRTL-5 cells, especially from early passes, retain a differentiated thyroid phenotype with respect to both their physical and functional properties. Clearly, there is a progressive loss of thyroid differentiation with repeated passage, we however did not achieve a completely dedifferentiated phenotype by passage 25 , the latest passage tested in this study. We believe that there will be a limit to the dedifferentiation and that eventually the FRTL-5 cells will reach a stable point and persist. The differences between early and late passage numbered cultures, characterized in this study, 
explain many of the unqualified features that have been ascribed to FRTL-5 cells. We found, under the conditions specified, that FRTL-5 cells from passes 3-15 form functional thyroid follicles, and display normal thyroid properties, including expression of $\mathrm{Cx} 32$ gap junctions, have a growth rate similar to primary thyrocytes and release $T_{4}$. Therefore, early passage cultures provide an excellent model to study thyroid function in vitro.

\section{ACKNOWLEDGEMENTS}

This work was supported by a NASA-Cooperative Research Agreement no. NCC9-79 with contributions from the Chan Shun International Foundation, Veterans Administration Merit Review Grant award (Green-0001) and Loma Linda University Basic Research Science Grant award (Green). We wish to thank Drs Daila S Gridley and Steve Todd for reviewing our manuscript and to Drs Mary LaBue and Robert Stagg for their support and advice.

\section{REFERENCES}

Ambesi-Impiombato FS, Parks LAM \& Coon HG 1980 Culture of hormone-dependent functional epithelial cells from rat thyroids. PNAS 77 3455-3459.

Ariga M, Nedachi T, Akahori M, Sakamoto H, Ito Y, Hakumo F \& Takahashi S 2000 Signaling pathways of insulin-like growth factor- 1 that are augmented by cAMP in FRTL-5 cells. Biochemical fournal 348 409-416.

Azuma H, Zeki K, Tanaka Y, Suzuki H, Yamashita U, Morimoto I \& Eto S 1990 Inhibitory effect of IL-1 on TSH dependent growth of rat thyroid cells (FRTL-5). Endocrinogia Faponica 37 619-627.

Backeljauw PF, Dai Z, Clemmons DR \& D'Ercole AJ 1993 Synthesis and regulation of insulin-like growth factor binding protein-5 in FRTL-5 cells. Endocrinology 132 1677-1681.

Balice-Gordon RJ, Bone LJ, Deschenes SM, Fischbeck KH \& Scherer SS 1998 X-linked Charcot-Marie-Tooth disease and connexin32. In Gap Functions in Health and Disease Meeting Report. Eds R Dermietzel \& F Hofstadter. Virchows Archiv 432 177-186.

Bastiaanse EM, Jogsma HJ, van der Laarse A \& Takens-Kwak BR 1993 Heptanol-induced decrease in cardiac gap junctional conductance is mediated by a decrease in the fluidity of membranous cholesterol-rich domains. Fournal of Membrane Biology 136 135-145.

Bellur S, Tahara K, Saji M, Grollman EF \& Kohn LD 1990 Repeatedly passed FRTL-5 rat thyroid cells can develop insulin and insulin-like growth factor-I-sensitive cyclooxygenase and prostaglandin E2 isomerase-like activities together with altered basal and thyrotropin-responsive thymidine incorporation into DNA. Endocrinology 127 1526-1540.

Beyer EC, Paul DL \& Goodenough DA 1987 Connexin43: a protein from rat heart homologues to a gap junction protein from liver. Fournal of Cellular Biology 105 2621-2629.

Brosing JW, Giese WL \& Mulcahy RT 1989 Lack of a differential radiation response for proliferative and non-proliferative rat thyroid cells (FRTL-5) in vitro. International Fournal of Radiation Oncology, Biology, Physics 16 1511-1517.

Cavalieri RR, Simeoni LA, Park SW, Baxter JD, Scharschmidt BF, Ribeiro RC \& Lomri N 1999 Thyroid hormone export in rat FRTL-5 thyroid cells and mouse NIH-3T3 cell carrier-mediated, verapamil-sensitive, and stereospecific. Endocrinology 140 4948-4954.

Chen G, Pekary AE, Sugawara M \& Hershman JM 1993 Effect of exogenous hydrogen peroxide on iodide transport and iodine organification in FRTL-5 rat thyroid cells. Acta Endocrinologica 129 89-96.

Christov K, Bollman R \& Thomas C 1973 Thyroid follicular cell proliferation as a function of age. Beitrage zur Pathologie 148 152-164.

Dahl G, Miller T, Paul D, Voellmy R \& Werner R 1987 Expression of functional cell-cell channels from cloned rat liver gap junction complementary DNA. Science 236 1290-1293.

Dai Z, Takajashi SI, VanWyk JJ \& D’Ercole AJ 1992 Creation of an autocrine model of insulin-like growth factor-I action in transfected FRTL-5 cells. Endocrinology 130 31753183.

Dermietzel R 1993 The gap junction channel. In Nonselective Cation Channels: Pharmacology, Physiology and Biophysics. Eds D Siemem \& J Hescheler. Basel: Birkhauser Verlag.

Deschenes SM, Walcott JL, Wexler TL, Scherer SS \& Fischbeck KH 1997 Altered trafficking of mutant connexin32. Fournal of Neuroscience 17 9077-9084.

Fairweather N, Bell C, Cochrane S, Chelly J, Wang S, Mostacciuolo ML, Monaco AP \& Haites NE 1994 Mutations in the connexin32 gene in X-linked dominant CharcotMarie-Tooth disease (CMTX1). Human Molecular Genetics 3 1034-1041.

Feinberg A \& Vogelstein B 1983 A technique for radiolabeling DNA restriction endonuclease fragments to high specific activity. Analytical Biochemistry 137 266-270.

Gallardo MH, Bickham JW, Honeycutt RL, Ojeda RA \& Kohler N 1999 Discovery of tetraploidy in a mammal. Nature 401341.

Green LM, Lazarus JP, LaBue M \& Shah MM $1995 a$ Reduced cell-cell communication in a spontaneous murine model of autoimmune thyroid disease. Endocrinology 136 $3611-3618$.

Green LM, LaBue M, Lazarus JP \& Colburn KK 1995 b Characterization of autoimmune thyroiditis in MRL-lpr/lpr mice. Lupus 4 187-196.

Green LM, LaBue M, Lazarus JP \& Jennings JC 1996 Reduced cell-cell communication in an experimentally induced thyroid disease. Endocrinology 137 2823-2832.

Green LM, Lazarus JP, Song X, Stagg RB, LaBue M \& Hilliker S 1997 Elevated protein kinase C in autoimmune diseased thyroid prevents assembly of connexin 43 gap junctions and reduces intercellular communication. Thyroid 7 913-921.

Green LM, Murray DK, Tran DT, Bant AM, Kazarians G, Moyers MF \& Nelson GA 2001 Response of thyroid follicular cells to gamma compared to proton radiation: I. Initial characterization of DNA damage, micronuclei formation, apoptosis, survival and cell cycle phase redistribution. Radiation Research 155 32-42.

Guerrier A, Fonlupt P, Morand I, Rabilloud R, Audebet C, Krutovskikh V, Gros D, Rousset B \& Munari-Silem Y 1995 Gap junctions and cell polarity: connexin32 and connexin 43 expressed in polarized thyroid epithelial cells assemble into separate gap junctions, which are located in distinct regions of the lateral plasma membrane domain. Fournal of Cell Science 108 2609-2617. 
Holder JW, Elmore E \& Barrett JC 1993 Gap junction function and cancer. Cancer Research 53 3475-3485.

Huber G, Derwahl M, Kaempf J, Peter HJ, Gerber H \& Studer H 1990 Generation of intercellular heterogeneity of growth and function in cloned rat thyroid cells (FRTL-5). Endocrinology 126 1639-1645.

Ionasescu V, Searby C \& Ionasescu R 1994 Point mutations of the connexin32 (GJB1) gene in X-linked dominant Charcot-Marie-Tooth neuropathy. Human Molecular Genetics 3 355-358.

Jordan K, Chodock R, Hand AR \& Laird DW 2001 The origin of annular junctions: a mechanism of gap junction internalization. Fournal of Cell Science 14 763-773.

Kerbel RS 1995 Significance of tumor-host interactions in cancer growth and metastases. Cancer and Metastasis Reviews $14259-262$.

Kimura T, Okajima F, Kikuchi T, Kuwabara A, Tomura H, Tomura H, Sho K, Kobayashi I \& Kondo Y 1997 Inhibition of TSH-induced hydrogen peroxide production by TNF-alpha through a sphingomyelinase-signaling pathway. American Fournal of Physiology 273 639-643.

Kojima T, Mitaka T, Paul DL, Mori M \& Mochizuki V 1995 Reappearance and long-term maintenance of connexin 32 in proliferating adult rat hepatocytes: use of serum-free L-15 medium supplemented with EGF and DMSO. Fournal of Cell Science 108 1347-1357.

Laird DW, Puranam KL \& Revel JP 1991 Turnover and phosphorylation dynamic of connexin 43 gap junction protein in cultured cardiac myocytes. Fournal of Biochemistry 273 $67-72$.

Loewenstein WR 1979 Junctional intercellular communication and the control of growth. Biochemica et Biophysica Acta $\mathbf{5 6 0}$ $1-65$.

Meda P 1989 Gap junctional coupling and secretion in endocrine and exocrine pancreas. In Cell Interactions and Gap Functions vol 1, pp 59-79. Eds N Sperelakis \& WC Cole. Boca Raton: CRC Press.

Meda P, Pepper MS, Traub O, Willecke K, Gros D, Beyer E, Nicholson B, Paul D \& Orci L 1993 Differential expression of gap junction connexins in endocrine and exocrine glands. Endocrinology 5 2731-2738.

Medina DL, Velasco JA \& Santisteban P 1999 Somatostatin is expressed in FRTL-5 thyroid cells and prevents thyrotropin-mediated down-regulation of the cyclindependent kinase inhibition by p27 kip1. Endocrinology 140 87-95.

Medina DL, Toro MJ \& Santisteban P 2000 Somatostatin interferes with thyrotropin-induced G1-S transition mediated by cAMP-dependent protein kinase and phosphadylinositol 3-kinase: involve RhoA and cyclin E x cyclin-dependent kinase 2 complexes. Fournal of Biological Chemistry 275 15549-15556.

Mehta PP, Perez-Stable C, Nadji M, Mian M, Asotra K \& Roos BA 1999 Suppression of human prostate cancer cell growth by forced expression of connexin genes. Developmental Genetics 24 91-110.

Miller T, Dahl G \& Werner R 1988 Structure of a gap junction gene: rat connexin-32. Bioscience Reports $\mathbf{8}$ $455-464$.

Mulcahy RT, Rosenkrans WA Jr, Penney DP \& Cooper RA 1985 The growth of FRTL-5 thyroid epithelial cells grown as multicellular spheroids in vitro. In Vitro Cellular and Developmental Biology 21 513-520.

Munari-Silem Y, Guerrier A, Fromaget C, Rabilloud R, Gros D \& Rousset B 1994 Differential control of connexin 32 and connexin 43 expression in thyroid epithelial cells. Evidence for a direct relationship between connexin 32 expression and histiotypic morphogenesis. Endocrinology 135 7724-7734.
Neveu MJ, Sattler CA, Sattler GL, Hully JR, Hertzberg EL, Paul DL, Nicholson BJ \& Pitot HC 1994 Differences in the expression of connexin genes in rat hepatomas in vivo and in vitro. Molecular Carcinogenesis 11 145-154.

Neveu MJ, Hully JR, Babcock KL, Vaughan J, Hertzberg EL, Nicholson BJ, Paul DL \& Pitot HC 1995 Proliferationassociated differences in the spatial and temporal expression of gap junction genes in rat liver. Hepatology 22 202-212.

Oshimura M \& Barrett JC 1986 Chemically induced aneuploidy in mammalian cells: mechanisms and biological significance in cancer. Environmental Mutagenesis 8 129-159.

Paul DL 1986 Molecular cloning of cDNA for rat liver gap junction protein. Fournal of Cellular Biology 103 123-134.

Pekary AE, Berg L, Wang J, Lee P, Dubinett SM \& Hershman JM 1995 TNF-alpha, TSH, and aging regulate TGF-beta synthesis and secretion in FRTL-5 rat thyroid cells. American Fournal of Physiology 268 808-815.

Pekary AE, Levin SR, Johnson DG, Berg L \& Hershman JM 1997 Tumor necrosis factor-alpha (TNF-alpha) and transforming growth factor-beta 1 (TGF-beta 1 ) inhibits the expression and activity of $\mathrm{Na}+/ \mathrm{K}(+)$-ATPase in FRTL-5 rat thyroid cells. Fournal of Interferon and Cytokine Research 17 185-195.

Rouger H, LeGuern E, Birouk N, Gouider R, Tardieu S, Plassart E, Gugenheim M, Vallat JM, Louboutin JP, Bouche P, Agid Y \& Brice A 1997 Charcot-Marie-Tooth disease with intermediate motor nerve conduction velocities: characterization of $14 \mathrm{Cx} 32$ mutations in 35 families. Human Mutation 10 443-452.

Saez JC, Berthoud VM, Moreno AP \& Spray DC 1993 Gap junctions. Multiplicity of controls in differentiated and undifferentiated cells and possible functional implications. Advances in Second Messenger and Phosphoprotein Research 27 163-198.

Salomon D \& Meda P 1986 Heterogeneity and contactdependent regulation of hormone secretion by individual Beta cells. Experimental Cell Research 162 507-520.

Scherer SS, Bone LJ, Deschenes SM, Able A, Balice-Gordon RJ \& Fischbeck KH 1999 The role of the gap junction protein connexin 32 in the pathogenesis of X-linked CharcotMarie-Tooth disease. Novartis Foundation Symposium 219 $175-185$.

Statuto M, Audebet C, Tonoli H, Selmi-Ruby, Rousset B \& Munari-Silem Y 1997 Restoration of cell-to-cell communication in thyroid cell lines by transfection with and stable expression of the connexins-32 gene. Impact on cell proliferation and tissue-specific gene expression. Fournal of Biological Chemistry 272 24710-24716.

Suzuki K, Mori A, Lavaroni S, Miyagi E, Ulianich L, Katoh R, Kawaoi A \& Kohn LD 1999 In vivo expression of thyroid transcription factor-1 RNA and its relation to thyroid function and follicular heterogeneity: identification of follicular thyroglobulin feedback suppressor of thyroid transcription factor-1 RNA levels and thyroglobulin synthesis. Thyroid 9 319-331.

Tasevski V, Benn D, Peters G, Luttrell B \& Simpson A 1998 The Fischer rat thyroid cell line FRTL-5 exhibits a nondiploid karyotype. Thyroid 8 623-626.

Temme A, Buchmann A, Gabriel HD, Nelles E, Schwarz M \& Willecke K 1997 High incidence of spontaneous and chemically induced liver tumors in mice deficient for connexin32. Current Biology 7 713-716.

Tonoli H, Falchon V, Audebet C, Calle A, Jarry-Guichard T, Statuto M, Rousset B \& Munari-Silem Y 2000 Formation of three-dimensional thyroid follicle-like structures by polarized cells made communication competent by transfection and stable expression of the connexin 32 gene. Endocrinology 141 1403-1413. 
Tsuda H, Asamoto M, Iwahori Y, Hori T, Ota T, Baba-Toriyama H, Uehara N, Kim DJ, Krutovskikh VA, Takasuka N, Tsuchiya T, Mutai M, Tatematsu M \& Yamasaki H 1996 Decreased connexin32 and a characteristic enzyme phenotype in clofibrate-induced preneoplastic lesions not shared with spontaneously occurring lesions in the rat liver. Carcinogenesis 17 2441-2448.

Unwin PNT \& Zampighi G 1980 Structure of the junction between communicating cells. Nature 283 545-549.

Willecke K, Jungbluth S, Dahl E, Hennemann H, Heynkes R \& Grzeschik KH 1990 Six genes of the human connexin gene family coding for gap junctional proteins are assigned to four different human chromosomes. European Fournal of Cellular Biology 53 275-280.

Winterhager E, Stutenkemper R, Traub O, Beyer E \& Willecke K 1991 Expression of different connexins genes in rat uterus during decidualization and at term. European Fournal of Cell Biology 55 133-142.

Yamasaki H, Krutovskikh V, Mesnil M, Tanaka T, Zaidan-Dagli ML \& Omori Y 1999a Role of connexin (gap junction) genes in cell growth control and carcinogenesis. Comptes Rendus de l'Academie des Sciences. Serie III, Sciences de la vie 322 151-159.
Yamasaki H, Omori Y, Krutovskikh V, Zhu W, Mironov N, Yamakage K \& Mesnil M $1999 b$ Connexins in tumour suppression and cancer therapy. Novartis Foundation Symposium 219 254-260.

Yap AS, Stevenson B, Keast J \& Manley S 1995 Cadherinmediated and apical membrane assembly defines distinct steps during thyroid epithelial polarization and lumen formation. Endocrinology $1364672-4680$.

Zimmer DB, Green CR, Evans WH \& Gilula NB 1987 Topological analysis of the major protein in isolate and intact rat liver gap junctions and gap junction derived from single membrane structures. Fournal of Biological Chemistry 262 $7751-7763$.

Zurzolo C, Gentilr R, Mascia A, Garbi C, Polistina C, Aloj L, Avvedimento VE \& Nitsch L 1991 The polarized epithelial phenotype is dominant in hybrids between polarized and unpolarized rat thyroid cell lines. Fournal of Cell Science 101 $65-73$.

RECEIVED 23 March 2001

ACCEPTED 17 May 2001 